\title{
A Late Middle Palaeolithic assemblage containing Levallois and bifacial objects from Saône-et-Loire, France: GH 3 at Grotte de la Verpillière II à Germolles
}

\author{
Jens A. Frick \\ Department of Early Prehistory and Quaternary Ecology, Institute of Pre- and Protohistory and Medieval \\ Archaeology, Eberhard Karls University of Tübingen. Schloss Hohentübingen, Burgsteige 11, 72070 Tübingen, \\ Germany. Email: jens-axel.frick@ifu.uni-tuebingen.de
}

\begin{abstract}
:
The site of Grotte de la Verpillière II, a rock shelter and corresponding cave tunnel, is situated in a cliff face of an Oxfordian massive, around $10 \mathrm{~km}$ West of Chalon-sur-Saône in Eastern France. The excavation at this site has recovered Middle Palaeolithic assemblages in three stratified sedimentological units. The richest of these assemblages derives from Geological Horizon (GH) 3 and is discussed here. It is preliminarily attributed to a Late Middle Palaeolithic context of OIS 3 to 4 using radiometric-dating techniques.

The assemblage combines Levallois reduction, bifacial objects and diverse 'opportunistic' reduction strategies. The Levallois reduction shows a high level of raw-material economy in the use of raw pieces and blanks whose morphology is close to the shape of desired configured cores. Other reduction strategies show a wider range of approaches to blank production. Bifacial objects include but are not limited to Keilmesser with tranchet blows. The condition of objects from GH 3 range from unused raw pieces, tested raw pieces, configured and exhausted cores, correction and central flakes, as well as some heated objects, frost shards, and debris. The majority of raw materials derive from sources nearby, but were clearly transported to the site. Only some pieces show evidence for transport of up to $100 \mathrm{~km}$ from source to site. The presence of specific reduction strategies on bifacial objects and the existence of tranchet-blow modification provide support for the attribution of the assemblage to the Keilmessergruppen assemblages from Central Europe.
\end{abstract}

Keywords: Middle Palaeolithic; eastern France; Levallois; bifacial objects, Keilmessergruppen

\section{Introduction}

\subsection{Context and research history}

In the second half of the $20^{\text {th }}$ century, two classification systems for Middle Palaeolithic industries of Western Europe were prevalent. On the one hand, Bordes' typological system clustered the lithic record into so-called facies (Bordes \& Bourgon 1951; Bordes 1953; 1961; 1981; 1984) using a variety of lithic types. On the other hand, Bosinski’s Leitformen concept used frequently-occurring lithic objects to organize artefacts into so-called Formengruppen

Published by the School of History, Classics and Archaeology, University of Edinburgh ISSN: 2055-0472. URL: http://journals.ed.ac.uk/lithicstudies/

This work is licensed under a Creative Commons Attribution 2.5 UK: Scotland License. 
(Bosinski 1963; 1967; 1970b; 1982; 2001). These approaches have many similarities, but are not congruent (mostly with regard to bifacial objects). The intensive research of the last quarter of the $20^{\text {th }}$ century concerning the Middle Palaeolithic record has demonstrated that these classification systems do not fit for all detected phenomena in space and time. This is especially true of assemblages that are located far from the 'homeland' of these classification systems.

The Middle Palaeolithic record of southern Burgundy presents an excellent example of assemblages that do not fit neatly into these classificatory schemes. Attempts at classification began in the 1970s with the publication of Keilmesser with tranchet blows (Prondniks) and their affinities from Grotte de la Verpillière I (also known as Germolles) by R. Desbrosse (Desbrosse \& Texier 1973; Desbrosse et al. 1976). Unfortunately, Desbrosse did not have recourse to a reliable chronological framework and had to make simple comparisons of available lithic objects (mostly material from $19^{\text {th }}$ century excavations and surface collections).

The excavation and preliminary analysis of the open-air site of Le Dessous de Bailly in Champlost, Yonne (excavation between 1981 and 1992, directed by Ch. Girard and Farizy) with a tentative ESR date between 45 and $65 \mathrm{ka}$ (EU of $48.1 \pm 4.4 \mathrm{ka}$ and LU of $56.7 \pm 4.2$ ka) and a Levallois industry with 'micoquoid' objects led Farizy (1995) to cluster similar assemblages from Saône-et-Loire (Bissy-sur-Fley, Blanzy, Saint-Martin-sous-Montaigu and Verpillière I), Yonne (Champlost, Vinneuf and Villeneuve-l'Archevéque), Haute-Saône (Frettes) and Nord-Pas-de-Calais (Riencourt-lès-Bapaume and Beuvry à Bethune) as Industries charentiennes à influences micoquiennes (CIM), which she attributed to contacts and influences of Mousterian and Micoquian cultures (Farizy 1995: 174). The definition of the CIM from Farizy (1995) includes highly-modified side-scrapers (backed, removed bulb, thinned back) and bifaces (partially bifacial retouched or plano-convex bifacial pieces) or Kostienki knives, and others, but as Farizy observed, these types do not fit into the Bordesian typology (Bordes 1961).

Since then, new chronological frameworks and assemblage analyses have produced a much more detailed picture, for example the studies conducted at the sites of Vinneuf or Champlost, Yonne and Verrière-le-Buisson, Essonne (Gouédo 1999), or the sites in the Senonnais, Yonne (Deloze et al. 1994) and Frettes, Haute-Saône (Lamotte et al. 2014).

On-going research on stratified archaeological layers at Grotte de la Verpillière I and II (VP I and II) offers new information for continued discussion of the classification and grouping of the Middle Palaeolithic record of this region and its place in space and time. First, lithic studies of museum and private collections from the Côte chalonnaise (the area around Chalon-sur-Saône, Burgundy) show that patterns detected in the stratified layers of VP I and II are present in other examples in the surrounding area (Herkert et al. 2015; Herkert 2016; Frick \& Floss in press). This research could contribute to the foundation of a chronologically bounded regional idiosyncrasy in Palaeolithic assemblages, and would promote the excellent research of C. Farizy and R. Desbrosse in this region and field of research.

This contribution focuses on the recently-excavated lithic assemblages (between 20092014) of GH 3 at VP II, which could be summarized as containing a Levallois reduction sequence paired with a variety of bifacial elements and diverse 'opportunistic' reduction sequences, attributed to the early OIS 3. This would fit into Farizy's description of the spatially extended CIM.

The task of this paper is now to discuss these observed lithic patterns in detail and to evaluate current evidence for the definition of lithic group formation unique to the region. 


\subsection{Site location and formation}

The site is located $10 \mathrm{~km}$ west of Chalon-sur-Saône in the commune of Mellecey, in the village of Germolles (Saône-et-Loire department, France, see Figure 1). The site name derives from the regional sub-district of La Verpillière. The caves are situated in the eastern cliff-face of the Upper Oxfordian Montadiot massif, which was affected by the formation of the RhineSaône-Rhône graben system. Karstic washing processes along two geological fractures formed both known archaeological sites (Cailhol 2016).

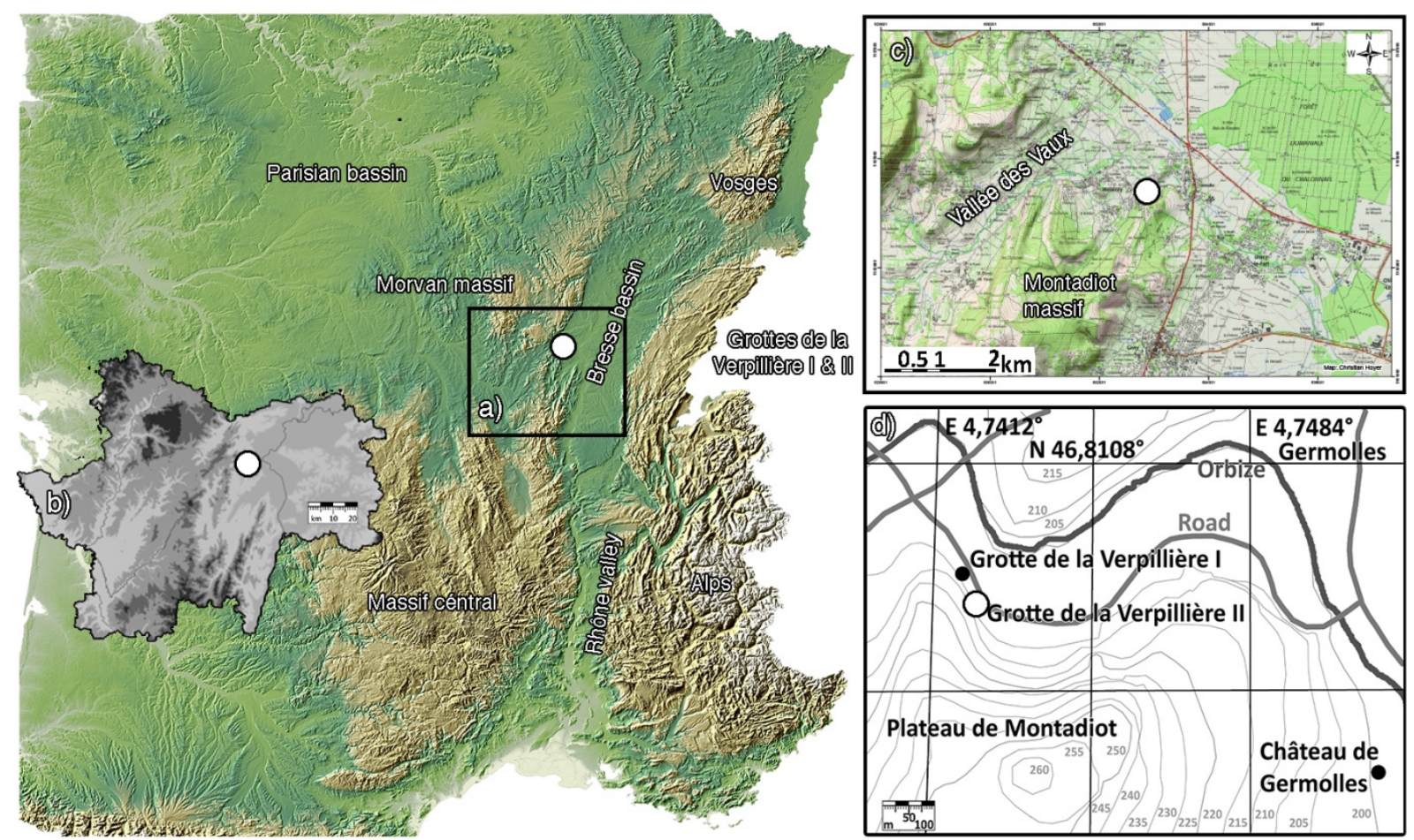

Figure 1. Location of Grotte de la Verpillière II (white point with black fringe). a) Position of Sâone-et-Loire department on a relief map of South-east France (NASA, SRTM 2000, www.pacha-cartographie.com); b) Relief map of Sâone-et-Loire department (NASA, SRTM 2000 from S.R.A Bourgogne); c) Logistic area around VP II on a topographical map (25k TOP map, Beaune-Chagny from the Institut géographique national, IGN 2005, GIS: Ch. Hoyer) and d) Immediate surrounding of VP II (Redrawn from 25k TOP map, Beaune-Chagny from the Institut géographique national, IGN 2005 and GoogleEarth map from 2011).

VP II was discovered in 2006 during excavations (directed by H. Floss) at the nearby Grotte de la Verpillière (VP I, also known as Grotte de Germolles). The sites are around $50 \mathrm{~m}$ apart in the same cliff face. Since then, parallel annual research excavations (fouilles programmées) at both sites (VP I and VP II) have been conducted.

The two sites are actually not "caves" (as was suggested at the times of their discovery), but rather collapsed rock-shelters. In the case of VP II, a connected cave tunnel extends to the south of the shelter. The excavations between 2009 and 2015 removed stratified sediments at the recent entrance of this cave tunnel (this paper discusses materials from excavations between 2009 and 2014). The majority of collapsed rocks from the former rock shelter remain in place. The early years of excavation (2006-2009) focused on the removal of mixed sediments (GH1, GH2; from landslide and animal activity but containing material associated to Middle Palaeolithic, Châtelperronian, early Upper Palaeolithic, Neolithic, Roman Age, Medieval and modern times) overlying this rock collapse. Only some of the large roofcollapse blocks were removed, to provide access to the cavity. Below this roof-collapse and smaller blocks from a less extensive ceiling collapse, three sedimentological units (GH 3, 4x and 4) bearing exclusively Middle Palaeolithic artefacts were found. An overview of the site 
history and the materials recovered up to 2013 can be found in Frick and Floss (2015). The discussed GH 3 is an up to 1-meter-thick layer of very homogeneous sediment (mixture of a high portion of Aeolian sediment and a small portion of fluvial sediment). During excavation, it was not possible to find sub-levels, but the detected charcoal distribution indicates that there should be sub-levels. All conducted research (Frick \& Floss 2015; Frick 2016a, 2016b) could only show tendencies in the spatial distribution and were not able to clearly separate the assumed sub-levels. The synthesized stratigraphy of the site is presented in Figure 2.

Assemblage attribution

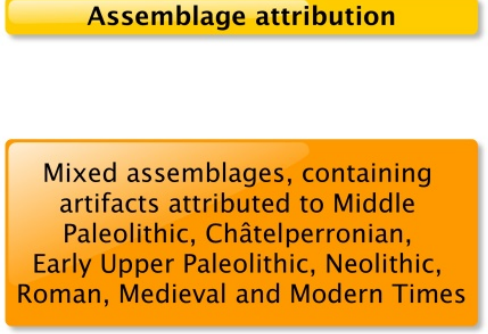

Stratified assemblage attributed to the Keilmessergruppen

Stratified assemblages attributed to the Middle Paleolithic (also KMG?)

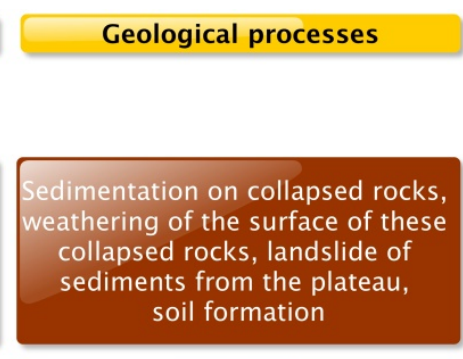

Second rock collapse
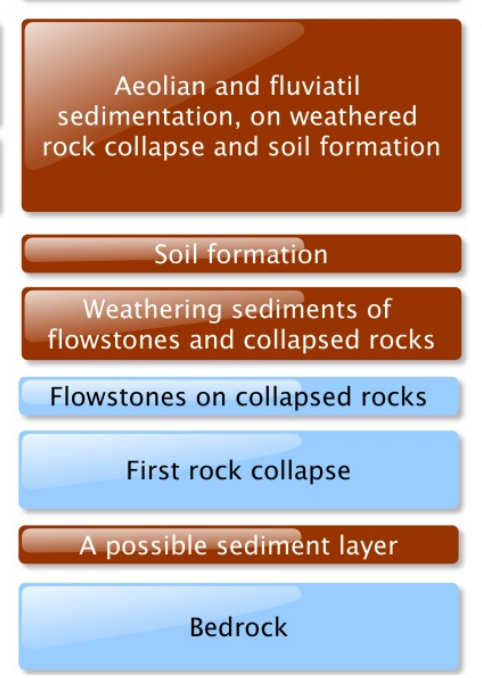

\section{Geological horizons with coarse position}
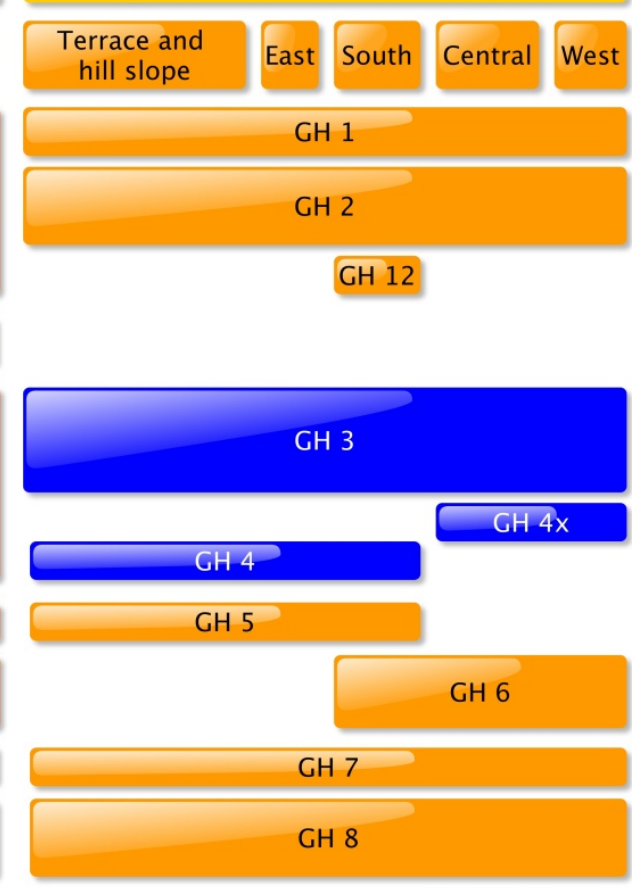

GH 9

GH 10

Figure 2. Synthesized stratigraphic sequence of VP II, divided into assemblage attribution, geological processes and defined geological horizons. (Image created using the free software yED from yWorks.)

\section{Methods: Recovery and analysis of lithic artefacts}

\subsection{Excavation methodology}

The majority of the analysed lithic objects $(>5 \mathrm{~mm}$ ) are single-finds, spatially recorded with a total station (tachymeter and laptop). The finds from 2009 derive from test-pit excavation and were recorded as collective finds (finds from a single bucket of sediment, recovered during excavation or water-screening, they are not individually spatially recorded, only the position of the sediment is spatially recorded). Zones excavated in this manner may show artificially lower find-density in projections such as that featured in Figure 3. Systematic excavation proceeded at a finer scale from 2010 on, with higher levels of stratigraphic control and the majority of objects recorded as single-finds (Figure 3). The excavation methodology is an updated variation on the Tübingen system, established by J. Hahn for excavations at Geißenklösterle or Hohle Fels (e.g., Hahn 1988) and described in unpublished manuscripts that are updated annually (Frick \& Hoyer 2009; 2011; 2012; Frick et al. 2013; Frick et al. 2014). 


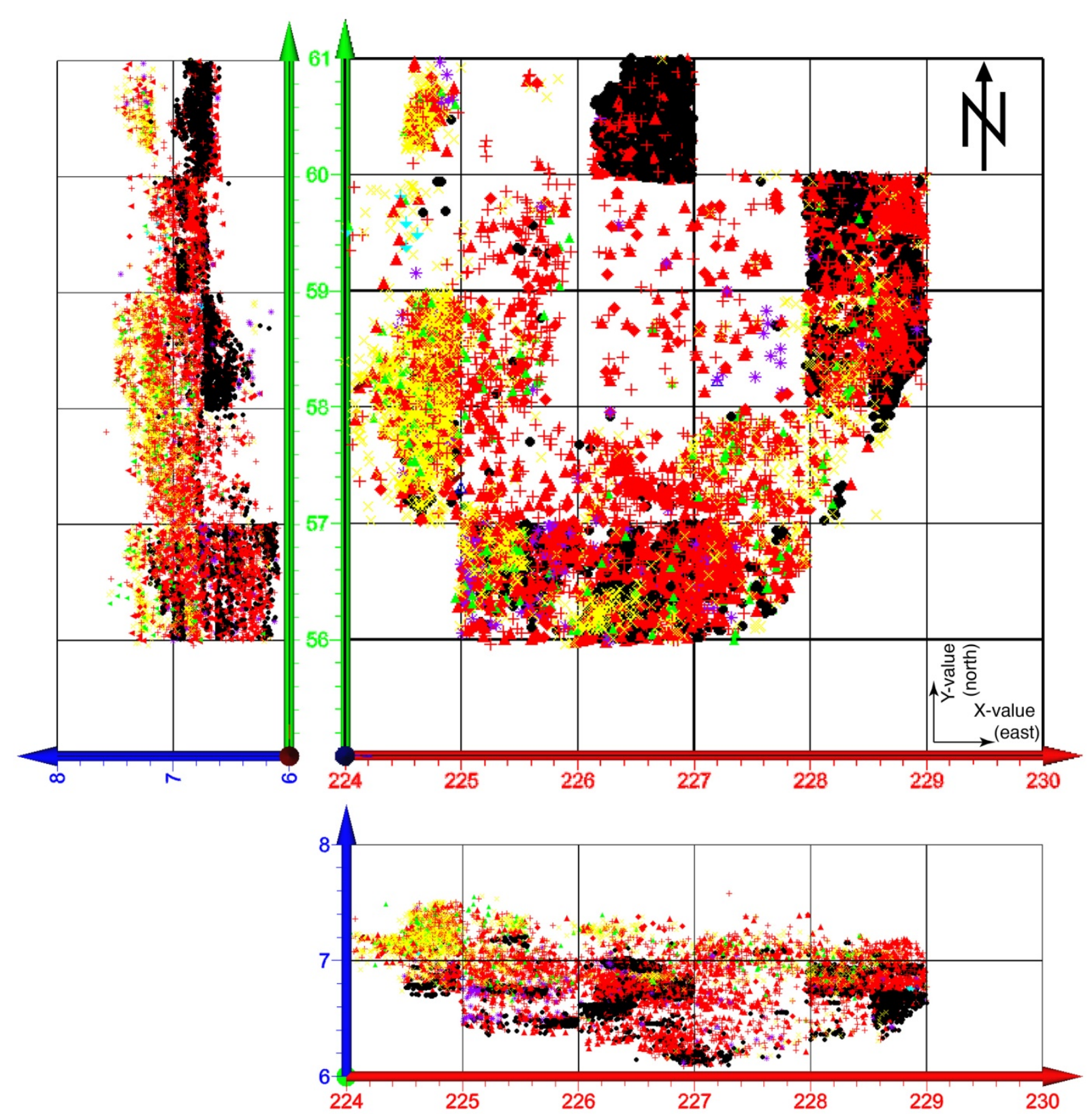

Figure 3. Spatial distribution of objects excavated from GH 3. Above left (view from East to West), above right (plan view) and bottom right (view from South to North). Abbreviated colour code: red - lithic objects; yellow bone; green - tooth; black - charcoal fragments. The sparser single-find density in the centre resulted for 2009 excavation techniques. (Figure by S. P. Steigerwald.)

The extent of GH 3 excavated thus far (estimated to be about $1 / 4$ of the total volume of this unit) contains $n=17,851$ objects: $n=3,770$ lithic objects $(n=2,961$ single finds and $n=809$ from collective finds), $n=8,711$ tiny charcoal fragments, $n=2,323$ faunal remains and $n=2,414$ limestone fragments. Metric data have thus far been collected on 2,444 of these lithic artefacts (see Section 2.4, below).

\subsection{Raw material identification}

The identification of lithic raw-material groups $(n=18)$ (see Tables 1 and 2) follows the methodology established by Floss (1994) and the on-going work of M. Siegeris and K. Herkert, who are performing detailed studies of lithic raw materials of the Middle and Upper Palaeolithic of southern Burgundy (see also Herkert et al. 2015; Herkert 2016; Siegeris 2016). 
The separation of raw material was done using geological methods, such as grain size, color, matrix, zoning in a macroscopic way. Microscopical analysis will be presented elsewhere (Siegeris 2016).

Table 1. Separation of lithic objects and number concerning all lithic raw materials from GH 3 (campaigns 2009 to 2014).

\begin{tabular}{|c|c|c|c|}
\hline 1. Separation & Criteria & 2. Separation & Number \\
\hline Raw piece & No detachments visible, unopened, no traces of use & Unused Raw piece & 36 \\
\hline Raw piece & No detachments visible, but specific traces of use & Hammerstone & 44 \\
\hline Raw piece & No detachments visible, but specific traces of use & Anvil & 11 \\
\hline Core & At least one detachment visible, traces of use & Core-of-hammerstone & 48 \\
\hline Core & At least one detachment visible, traces of use & Core-of-anvil & 8 \\
\hline Core & $\begin{array}{l}\text { At least one detachment visible, beginning of } \\
\text { decortication, but discarded because of failures ('bad' } \\
\text { raw material or knapping mistakes) }\end{array}$ & Tested raw piece & 57 \\
\hline Core & $\begin{array}{l}\text { At least one detachment visible, decortication and } \\
\text { beginning of configuration, but discarded because of } \\
\text { failures ('bad' raw material or knapping mistakes) }\end{array}$ & Core-preform & 12 \\
\hline Core & $\begin{array}{l}\text { Some detachments on positions where possible, often } \\
\text { reduction in several directions }\end{array}$ & Opportunistic cores & 62 \\
\hline Core on blank & $\begin{array}{l}\text { Reduction on ventral face of a blank, in the sense of } \\
\text { Tixier and Turq (1999) and Frick (2013) }\end{array}$ & $\begin{array}{l}\text { Ventral core (Kombewa } \\
\text { core) }\end{array}$ & 10 \\
\hline Core on blank & $\begin{array}{l}\text { Reduction on dorsal face of a blank, in the sense of } \\
\text { Tixier and Turq (1999) and Frick (2013) }\end{array}$ & $\begin{array}{l}\text { Dorsal core (Kostienki } \\
\text { cores) }\end{array}$ & 6 \\
\hline Core on blank & $\begin{array}{l}\text { Independent reduction on ventral and dorsal face of a } \\
\text { blank (both, but separated) }\end{array}$ & $\begin{array}{l}\text { Ventral and dorsal core } \\
\text { (Kombewa and } \\
\text { Kostienki core) }\end{array}$ & 6 \\
\hline Core & $\begin{array}{l}\text { Matrix is a raw piece or object is completely } \\
\text { overprinted, bifacial reduction on surfaces and edges } \\
\text { for making a tool, see also Frick and Floss (in press) }\end{array}$ & $\begin{array}{l}\text { Bifacial object made on } \\
\text { core }\end{array}$ & 3 \\
\hline $\begin{array}{l}\text { Core on frost } \\
\text { shard }\end{array}$ & $\begin{array}{l}\text { Matrix is a frost shard, bifacial reduction on surfaces } \\
\text { and edges for making a tool, , see also Frick and Floss (in } \\
\text { press) }\end{array}$ & $\begin{array}{l}\text { Bifacial object made on } \\
\text { frost shard }\end{array}$ & 4 \\
\hline Core & $\begin{array}{l}\text { Two inclined reference planes, but in this case only } \\
\text { some removals are detached (Quina core or SSD-core?), } \\
\text { in the sense of Turq (1989) and Bourguignon (1996; } \\
\text { 1997) }\end{array}$ & $\begin{array}{l}\text { Core with Quina-like } \\
\text { reduction }\end{array}$ & 1 \\
\hline $\begin{array}{l}\text { Core on raw } \\
\text { piece or blank }\end{array}$ & $\begin{array}{l}\text { Unidirectional and bidirectional removals inclined to the } \\
\text { reference plane, in the sense of Terradas (2003) and } \\
\text { Slimak (2004) }\end{array}$ & Discoidal core & 4 \\
\hline $\begin{array}{l}\text { Core on raw } \\
\text { piece or blank }\end{array}$ & $\begin{array}{l}\text { Removals parallel to the reference plane, criteria after } \\
\text { Van Peer (1992) and Boëda (1994) }\end{array}$ & Levallois core & 23 \\
\hline $\begin{array}{l}\text { Core on frost } \\
\text { shard }\end{array}$ & Frost shard with a burin facet & Burin on frost shard & 1 \\
\hline Core & Fragment of a core, affiliation not visible & Core-debris & 2 \\
\hline Blank & $\begin{array}{l}\text { Object from a detachment process on a cortical surface, } \\
\text { belonging to the first removals on a raw piece with } \\
\text { cortex }\end{array}$ & Raw-piece cap & 228 \\
\hline Blank & $\begin{array}{l}\text { Blank from coarse raw material, showing traces of } \\
\text { impacts before the detachment }\end{array}$ & $\begin{array}{l}\text { Blank from } \\
\text { hammerstone or anvil }\end{array}$ & 27 \\
\hline Blank & $\begin{array}{l}\text { Blank that is removed in order to shape surfaces and } \\
\text { edges on cores (core configuration), such as débordant } \\
\text { blanks (core edge blanks), core tablets, predetermining } \\
\text { blanks) }\end{array}$ & Correction blank & 656 \\
\hline
\end{tabular}




\begin{tabular}{|c|c|c|c|}
\hline 1. Separation & Criteria & 2. Separation & Number \\
\hline Blank & $\begin{array}{l}\text { Blank deriving from Levallois reduction and is seen as } \\
\text { target blank (predetermined blank), in the sense of } \\
\text { Boëda (1994) and Van Peer (1992) }\end{array}$ & Levallois blank & 156 \\
\hline Blank & $\begin{array}{l}\text { Blank was detached from the ventral face of another } \\
\text { blank (evidence for the presence of two "ventral faces" } \\
\text { on the blank), in the sense of of Tixier and Turq (1999) } \\
\text { and Frick (2013) }\end{array}$ & $\begin{array}{l}\text { Ventral blank } \\
\text { (Kombewa blank) }\end{array}$ & 13 \\
\hline Blank & $\begin{array}{l}\text { Blank deriving from lateral-parallel sharpening of active } \\
\text { edges (Schneidenschlag-Abschlag) in the sense of Jöris } \\
\text { (2001) or Cornford (1986) }\end{array}$ & Tranchet-blow blank & 9 \\
\hline $\begin{array}{l}\text { "Core" on } \\
\text { blank }\end{array}$ & $\begin{array}{l}\text { Bifacially modified blank on surfaces and edges, see also } \\
\text { Frick and Floss (in press) }\end{array}$ & Bifacial object on blank & 19 \\
\hline Blank & Blank deriving from retouch processes & $\begin{array}{l}\text { Blank deriving from } \\
\text { retouch }\end{array}$ & 69 \\
\hline Blank & Simple blanks without specification & Other blanks & 1028 \\
\hline Heat debris & $\begin{array}{l}\text { Debris with traces of heat, in the sense of Frick et al. } \\
\text { (2012) }\end{array}$ & Heat debris & 138 \\
\hline Frost shard & Detached by frost process without further detachments & Frost shard & 114 \\
\hline $\begin{array}{l}\text { Knapping and } \\
\text { break debris }\end{array}$ & Remaining quantity & $\begin{array}{l}\text { Knapping and break } \\
\text { debris }\end{array}$ & 975 \\
\hline Total & - & - & 3770 \\
\hline
\end{tabular}

Table 2. Silicious raw materials from GH 3.

\begin{tabular}{lcccc}
\hline Lithic raw material & $\begin{array}{c}\text { Total } \\
\text { quantity } \\
(\mathbf{n})\end{array}$ & $\begin{array}{c}\text { Total } \\
\text { quantity } \\
\mathbf{( \% )}\end{array}$ & $\begin{array}{c}\text { Mass (g) of } \\
\mathbf{n = 2 4 4 4}\end{array}$ & $\begin{array}{c}\text { Mass (\%) of } \\
\mathbf{n = 2 4 4 4}\end{array}$ \\
\hline Flint from the argiles à silex (FAS) & 2899 & 74.27 & 33807.58 & 43.1550 \\
Unknown flint & 241 & 6.39 & 746.2 & 0.9507 \\
Lacustrine flint (Tertiary or Paleogene) & 4 & 0.11 & 1.8 & 0.0023 \\
Jurassic chert (Chaille) & 80 & 2.12 & 1815.3 & 2.3129 \\
Quartzite & 246 & 6.53 & 26429.2 & 33.6738 \\
Quartzitic sandstone & 28 & 0.74 & 4206.7 & 5.3598 \\
Sandstone & 81 & 2.15 & 6590.6 & 8.3972 \\
Quartz & 160 & 4.24 & 4337.88 & 5.5270 \\
Granite & 47 & 1.25 & 80.6 & 0.1027 \\
Arkose & 2 & 0.05 & 288.5 & 0.3676 \\
Conglomerate & 1 & 0.03 & 0.3 & 0.0004 \\
Feldspar & 10 & 0.27 & 5.9 & 0.0075 \\
Mica & 3 & 0.08 & 0.1 & 0.0001 \\
Pyrolusite & 1 & 0.03 & 10.5 & 0.0134 \\
Volcanic material & 2 & 0.05 & 23.8 & 0.0303 \\
Argilite & 12 & 0.32 & 0.1 & 0.0001 \\
Non-determined siliceous raw material & 241 & 6.32 & 72,3 & 0.0921 \\
\hline Total & $\mathbf{3 7 7 0}$ & $\mathbf{1 0 0}$ & $\mathbf{7 8 , 4 8 5 . 8 6}$ & $\mathbf{1 0 0}$ \\
\hline
\end{tabular}




\subsection{Spatial analysis and lithic refits}

The method of data-collection followed from 2010-2014 (total station and computational processing) allows for three-dimensional plotting of every point measured in the field (the precise methodology is discussed in Frick 2016a). All single-finds have precise threedimensional coordinates $( \pm 1 \mathrm{~cm})$ and collective finds are tied to the quarter-square-meter from which they were recovered. As an example, the entirety of excavated materials from $\mathrm{GH}$ 3 is displayed in Figure 3, color-coded by type and presented in three orientations.

Lithic refitting was undertaken in 2010, 2013 and 2015, as well as during the excavation in the case of refits that were obvious in the field or post-field processing (see Figures 4 and 5). Unfortunately, very little of the lithic material could be refit. At present, we attribute this to the fact that a maximum of one quarter (see Figure 6h) of the overall sediments of GH 3 (Figure 6e) have been excavated, and do not represent the centre of the occupation surface, which is expected to be under the collapsed roof blocks (see Figure 6, especially 6.d and 6.f).

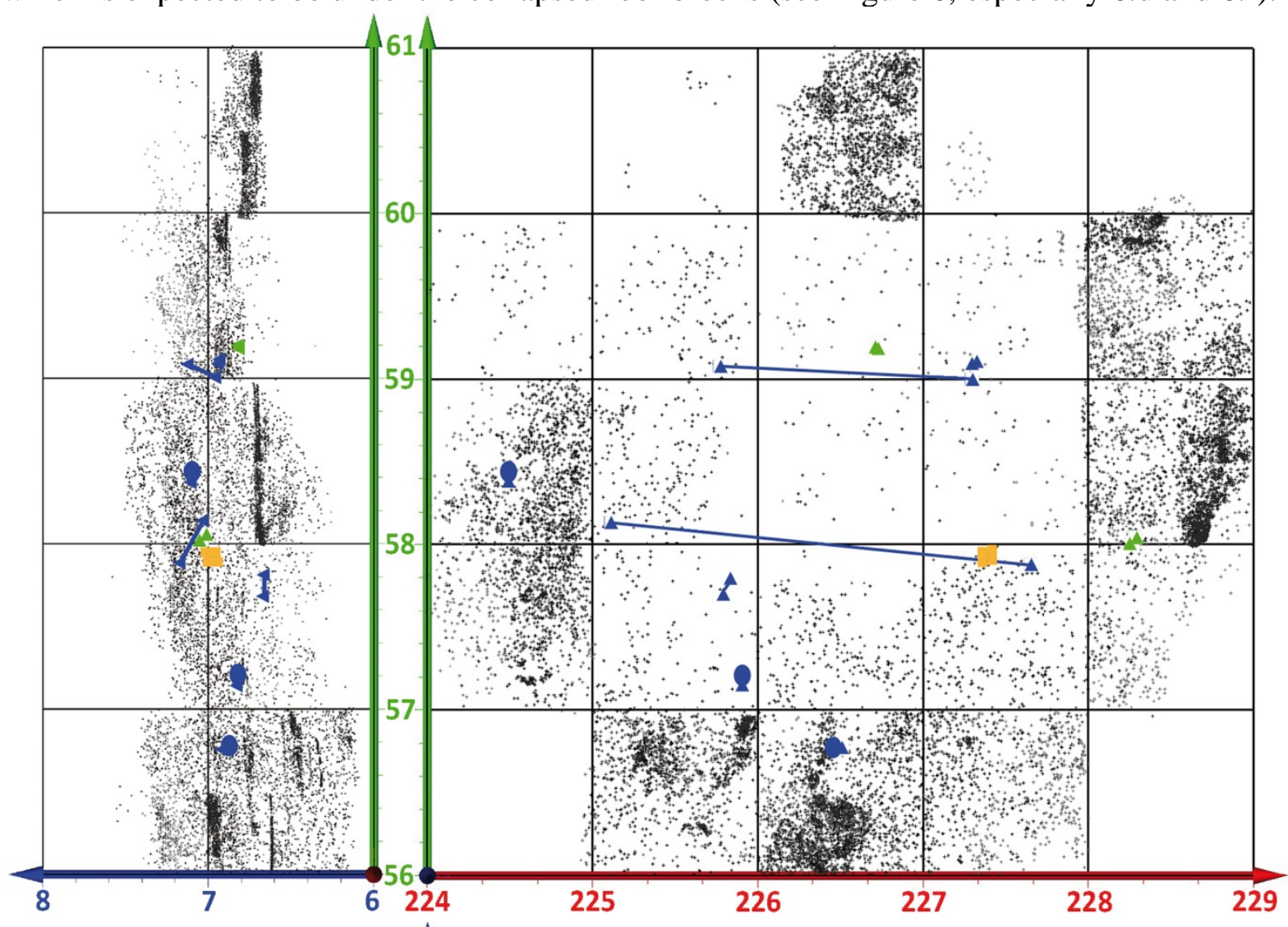

Refitting of a lithic production sequence

- Core

\ Blank

\section{Refitting of break}

$\Delta$ Blank fragment

I. Tooth fragment

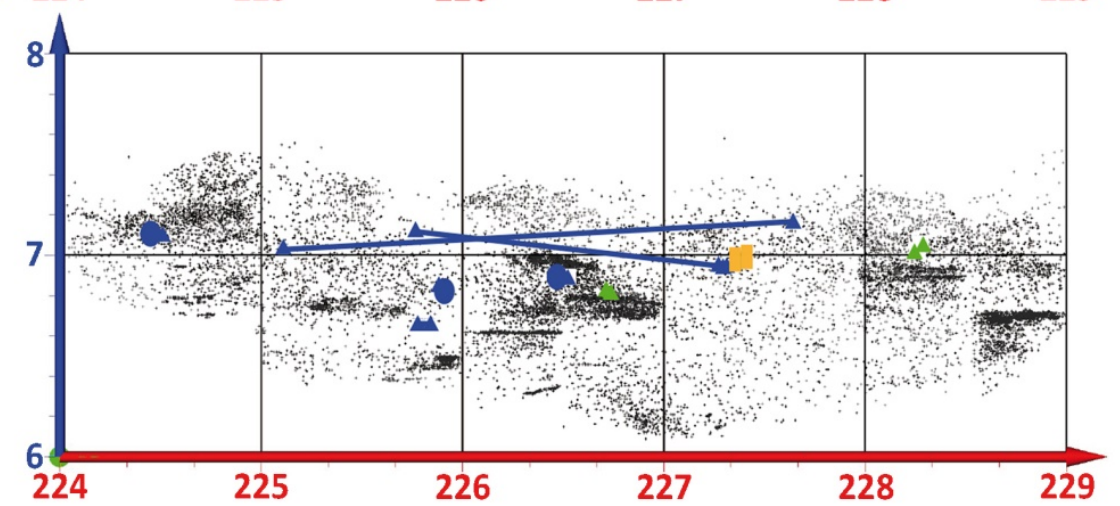

Figure 4. Refits of objects from GH 3. (Compilation by J.A. Frick and S. P. Steigerwald.) 


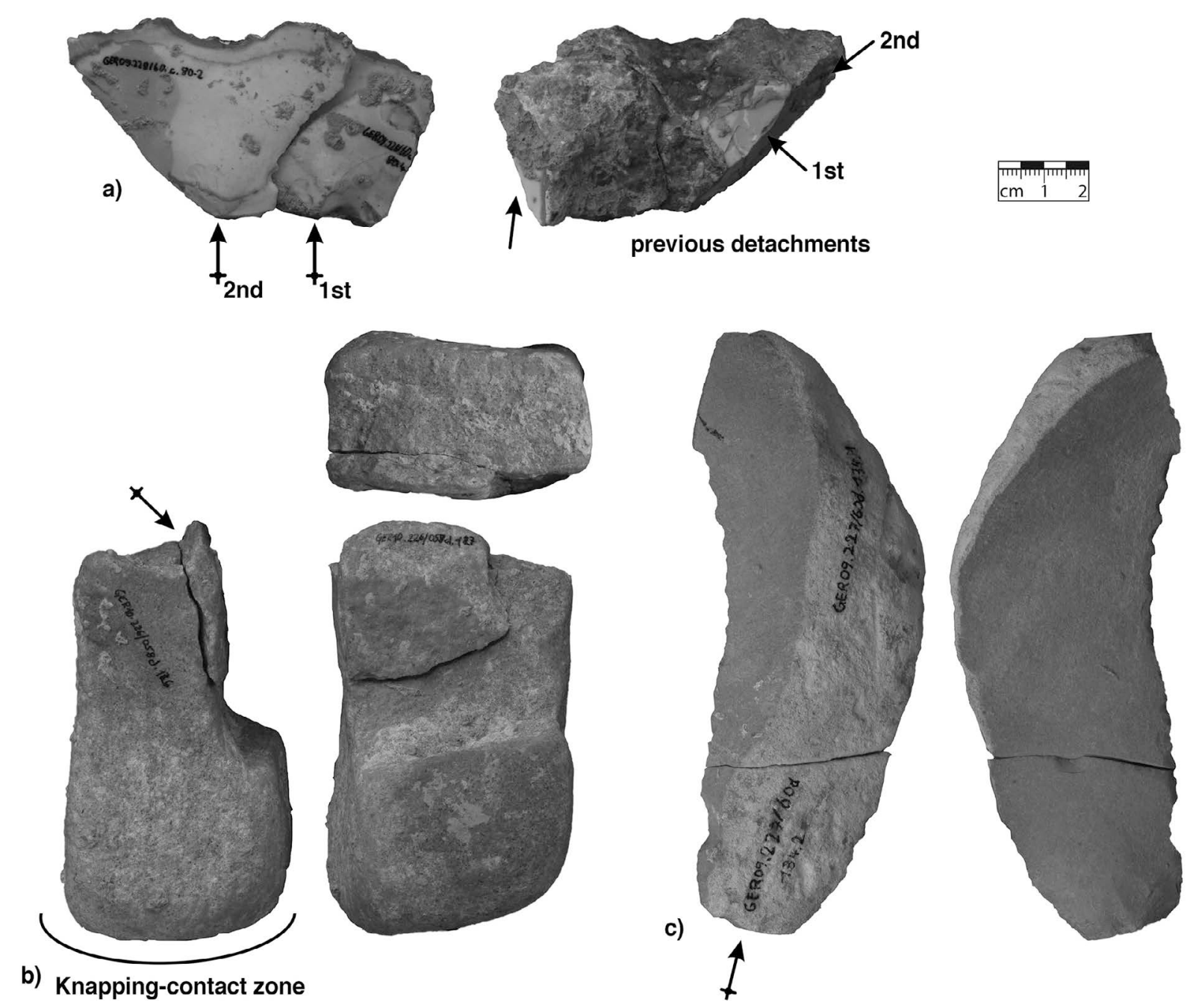

Figure 5. Examples of refits from GH 3. a) Refit of two cortical flakes in succession (FAS, GER09.228-060.80.2 and GER09.228-060.80.4); b) Refit of hammerstone and corresponding flake (Quartzite, GER12.225-059.892 and GER12.225-059.893); c) Refit of ancient break (chert, GER09.227-060.134.1 and GER09.227-060.134.2).

\subsection{Stratigraphic security of the lithic industry}

Several lines of evidence indicate minimal post-depositional movement inside of GH 3: micromophological analyses (Floss 2009; Wißing 2012), geomorphological studies (Bons \& Wißing 2009; Cailhol 2014; 2016), the predominantly horizontal orientation of artefacts (with the exception of a dozen pieces deposited between limestone blocks), and the sharp edges observed on lithic objects. Even so, chemical processes have altered the sediments (homogenisation of aeolian, and, to a lesser degree, fluvial sediments) and the lithic objects (opaque patination and sometimes impregnation by iron oxides; pers. comm. M. Siegeris). Due to such alteration, the background radiation fluctuates in the sediment (Richard et al. 2016).

A study of the spatial distribution of material from GH 3 (Frick 2016a) shows that specific object-types are not randomly distributed. For instance, faunal remains cluster in the upper part of GH 3 in the West, charcoal and limestone, as well as burnt and unburnt materials are always spatially separated. On the other hand, particular lithic types are not clustered (e.g., Levallois cores and blanks).

Clear horizontal organization of the material in GH 3 is further supported by distribution of lithic refits (Figures 4 and 5). Though limited, they are also almost entirely horizontally orientated, at distances up to $2.5 \mathrm{~m}$. 


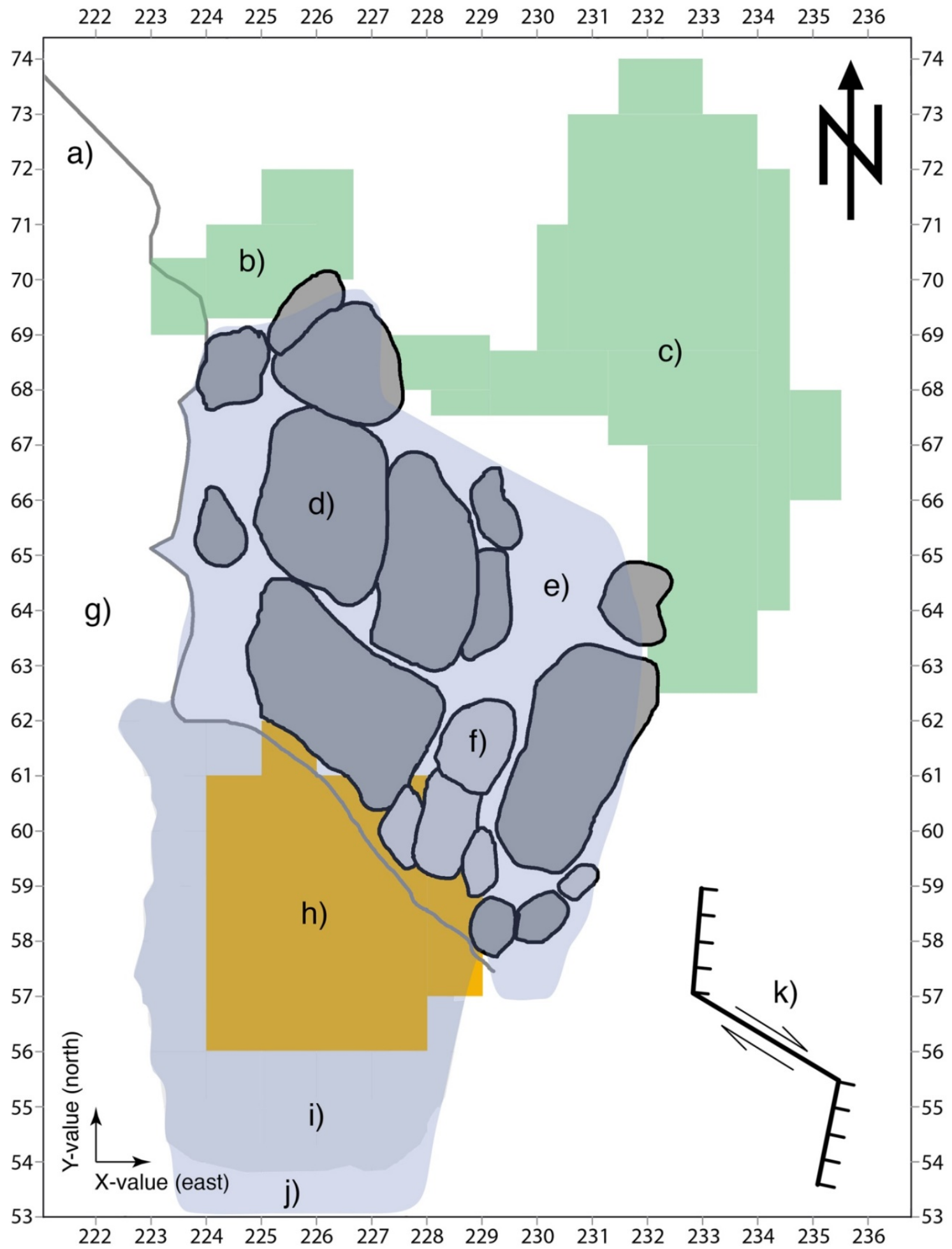

Figure 6. Schematic map of VP II showing: a) The cliff face (falaise), extending in the north-western direction toward VP I; b) Test pit $(2014,2015)$ to evaluate the extent of stratified sediments in the northern direction, removal (décapage) of mixed sediments; c) Test pit (2015) to evaluate the extent of stratified sediments and determine the slope of the bedrock, removal (décapage) of mixed sediments; d) Collapsed limestone blocks that once formed the rock-shelter and remain where they fell (dark grey); e) Area where sediments of GH 1 and 2 are almost completely removed (roughly equivalent to the potential area of stratified sediments); f) Original position of collapsed roof-blocks that have been removed (light grey); g) Plateau of the Montadiot massif; h) Position of the current excavation (2010-2015) of GH 3, GH 4x and GH 4 at the entrance of the cave tunnel; i) Measured extent of the cave tunnel; j) Presumed extent of the cave tunnel and of stratified sediments and $k$ ) Illustration of geomorphological fracture directions. (Basal GIS map from Ch. Hoyer, redrawn and completed by J. A. Frick and S. P. Steigerwald.) 


\subsection{Reduction-sequence, attributes and measurements}

All lithic artefacts are sorted into a hierarchical system of lithic reduction classes (see Table 1) which corresponds to steps in an operational chain (e.g., Geneste 1985). In addition, the succession of detachments (negatives) on cores and bifacial objects were observed, constitute another operational chain of reduction. This methodology is called schéma diacritique (Dauvois 1976) and was used on Levallois cores (e.g., Boëda 1994). A similar approach is called Herstellungsanalyse or Arbeitsschrittanalyse (e.g., for bifacial objects, see Jöris 2001; Richter 2013) and has been applied in the analysis of all bifacial objects known from both sites (see Frick \& Floss in press). Newly, the method of analysing removal succession on reduction surfaces of cores is impressively explained in Pastoors et al. (2015). In this work the succession of detachment clusters is illustrated using a grey-scale code.

The sorting system applied divided materials into: raw pieces (unworked nodules), cores (pieces bearing at least one negative of removal), blanks (detached objects), frost shards, and debris (heating debris and debris from knapping and breakage). Problematic in this context is that the matrix of a core can be an unused raw piece, a formerly reduced core, a frost shard or a blank. The term blank ('Grundform' in German) summarize all intentionally detached objects, such as flakes, blades, micro-flakes and bladelets that are produced from cores (débitage). These categories were further subdivided as shown in Table 1.

Currently, there is detailed attribute and metric data for $n=2,444$ of the lithic objects recovered. In addition to data on spatial position and raw material, knapping attributes and measurement data (dimensions, edge angles, extent of retouch, mass) were collected. An extensive list of attributes was composed after the refitting work of 2010, when it became clear that little data would be available based on refits, and alternative sources of information would need to be sought.

\section{Results}

\subsection{Sourcing of lithic raw materials}

All lithic raw materials at VP II were imported to the site and are present in different phases of the reduction sequence (from raw pieces to debris). The closest current sources (for flint of the argiles à silex type, FAS) are in close proximity to the site: around $150 \mathrm{~m}$ southwest on the Montadiot plateau and 120 m east (for small and rounded felsic rocks in the Orbize river; see also Herkert et al. (2015). FAS is a cretaceous flint in secondary position and was re-deposited in the Paleogene. Chert are only found in sub-primary positon and should derive from the vallée des Vaux (Herkert et al. 2015). Documented areas with sources of FAS and chert are located in an approximately 10-km radius around the site (Figure 7) and demonstrate sufficient raw-material sources on the landscape for the activities represented at the site. The heterogeneity of FAS makes it very challenging to explicitly denominate one source. The maximum transport distance recognized, for the lacustrine flints (tertiary silex, freshwater silex, probably of the Étrelles type), is around $120 \mathrm{~km}$ to the northeast on the northern margin of the Bresse basin (Herkert et al. 2015).

\subsection{Raw materials}

The excavated area of GH 3 contains $n=3,770$ lithic objects. The mass of all pieces that have been weighed $(n=2,444)$ equals $78.5 \mathrm{~kg}$ (the remaining is mostly debris). The primary lithic material is FAS, followed by quartzite (see Table 2). Chert, quartzitic sandstone, sandstone, and quartz are present in amounts of more than $1 \mathrm{~kg}$. The exogenous lacustrine flint is only represented by $n=4$ pieces. Materials used in the form of hammerstones and anvils are quartzite, quartzitic sandstone, sandstone, quartz and arkose. 


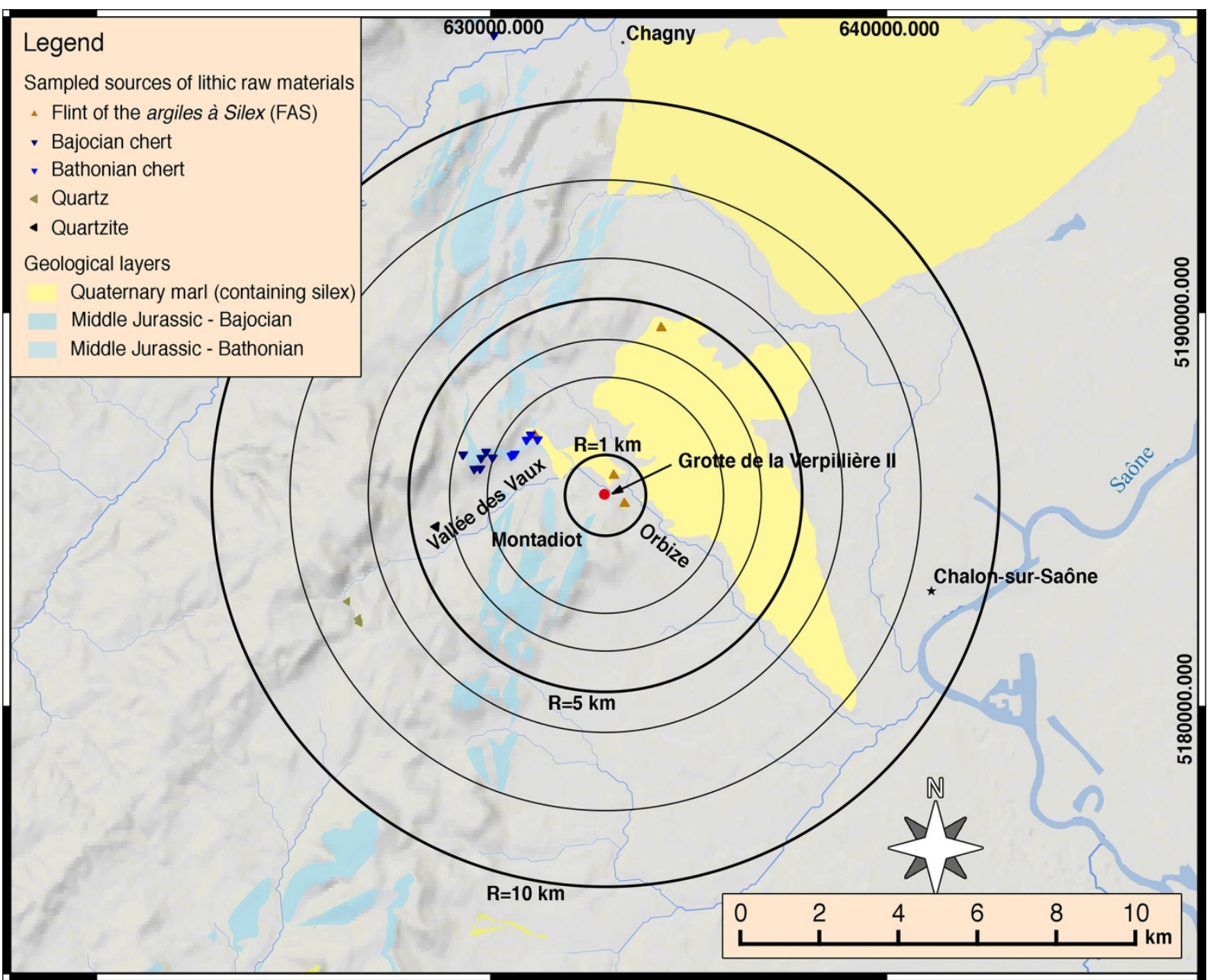

Figure 7. Distribution of sediments containing Jurassic chert (blue) and Flint from the argiles à silex (yellow) in the Côte chalonnaise (wider area of Chalon-sur-Saône). Map provided by M. Siegeris, base map from NASA Shuttle Radar Topography Mission 2000 (Jarvis et al. 2008) and raw material distribution by M. Siegeris.

\subsection{Composition of the lithic assemblage}

The lithic material has been grouped into categories based on the reduction process. If all raw materials are taken into account, there are $n=91$ complete raw pieces, $n=248$ cores and $\mathrm{n}=2201$ blanks (see Table 3).

Table 3. Clusters of lithic objects from GH 3, all raw materials

\begin{tabular}{|c|c|c|c|c|c|c|c|c|c|c|}
\hline \multirow[t]{2}{*}{$\begin{array}{c}\text { Raw } \\
\text { pieces }\end{array}$} & \multicolumn{3}{|c|}{ Cores } & \multicolumn{4}{|c|}{ Blanks } & \multicolumn{3}{|c|}{ Others } \\
\hline & $\begin{array}{l}\text { cores } \\
\text { on raw } \\
\text { pieces }\end{array}$ & $\begin{array}{c}\text { cores } \\
\text { on } \\
\text { blanks }\end{array}$ & $\begin{array}{c}\text { cores } \\
\text { on } \\
\text { frost } \\
\text { shards }\end{array}$ & flakes & blades & $\begin{array}{l}\text { micro- } \\
\text { flakes }\end{array}$ & bladelets & $\begin{array}{l}\text { heat } \\
\text { debris }\end{array}$ & $\begin{array}{c}\text { frost } \\
\text { shards }\end{array}$ & debris \\
\hline 91 & 194 & 42 & 12 & 1888 & 120 & 151 & 42 & 137 & 118 & 975 \\
\hline
\end{tabular}

The ratio of cores to blanks when all raw materials are considered is 1:9 (see Table 4) and if only fine-grained materials are considered (FAS, chert, lacustrine flint and unknown flint) are take into account it is $1: 11$. This ratio could reflect that the assemblage is incomplete, even if only minimal initialization and configuration is presumed. This pattern remains largely consistent when calculated for individual raw materials. For example, for 
FAS, there are $n=2,050$ objects including $n=1,875$ blanks and $n=175$ cores (a core-to-blank ratio of 1:10.7). Many cores from FAS seem to be heavily reduced, showing more than $n=11$ detachment negatives each. For felsic raw materials (e.g., for quartzite and quartz), these ratios are reversed (1:08). On the other hand, lacustrine flint is only present as blanks.

Table 4. Core-to-blank ratio by lithic raw material. (Number of cores = cores-on raw pieces, cores-on-blanks and cores-on-frost shards.)

\begin{tabular}{lccc}
\hline Raw material & $\begin{array}{c}\text { Number of } \\
\text { cores }\end{array}$ & $\begin{array}{c}\text { Number of } \\
\text { blanks }\end{array}$ & $\begin{array}{c}\text { Core-to-blank } \\
\text { ratio (rounded) }\end{array}$ \\
\hline FAS & 175 & 1875 & $1: 10.7$ \\
Unknown flint & 5 & 42 & $1: 8.4$ \\
Lacustrine flint & 0 & 4 & $0: 4$ \\
Jurassic chert & 4 & 53 & $1: 13.25$ \\
Quartzite & 24 & 19 & $1: 0.79$ \\
Quartzitic sandstone & 11 & 4 & $1: 0.36$ \\
Sandstone & 19 & 7 & $1: 0.37$ \\
Quartz & 3 & 14 & $1: 4.67$ \\
Arkose & 1 & 0 & $1: 0$ \\
Argilite & 1 & 0 & $1: 0$ \\
Undetermined siliceous raw material & 5 & 187 & $1: 37.4$ \\
\hline Total & $\mathbf{2 4 7}$ & $\mathbf{2 2 0 5}$ & $\mathbf{1 : 9}$ \\
\hline
\end{tabular}

Raw pieces (unopened or complete nodules, also called manuport) are present for FAS, chert, quartzite, quartzitic sandstone, quartz and sandstone, which serves as another argument for close distance transportation of these materials. These materials are also present as cores and blanks, as well as knapping debris, an argument for on-site transformation.

The majority of cores and blanks from FAS, chert, unknown flint and unknown raw materials falls into "flake dimension" (between $\mathrm{L}>\mathrm{W}$ and $\mathrm{L}<\mathrm{W} / 2$ ) (see Figure 8). Blades are present from FAS and chert. The presence of bladelets is very limited and they are only made from FAS. In general, cores are larger than blanks. The L/W distributions of this FAS shows a steady decrease in number by increasing size, a evidence for a dimensionally complete assemblage and on-site transformation (Weißmüller 1995: 62-63). This pattern is different for chert, unknown flint and unknown raw material. For chert, blanks are mostly smaller than 70 by $70 \mathrm{~mm}$ (the exception is displayed in Figure 6c).

\subsection{Raw pieces, hammerstones and anvils}

In $\mathrm{GH} 3, \mathrm{n}=91$ raw pieces were recovered. Raw material composition of this type is as follows: quartzite $(n=44)$, FAS $(n=16)$, quartz $(n=14)$, sandstone $(n=12)$, quartzitic sandstone $(n=4)$ and chert $(n=1)$. The raw pieces of quartzite were mostly used as hammerstones and anvils (based on zones of shattering and crushed areas). The raw pieces in FAS show no traces of use or breakage. Quartz is present in the form of hammerstones, anvils and small pebbles. All raw pieces from quartzitic sandstone are classified as hammerstones. A single nodule of chert also shows no traces of use. Overall, $n=111$ objects, all in coarse-grained materials, are categorized as hammerstones (Table 5) and anvils (Table 6). Objects within these two categories are also classified as raw pieces (no removal scars) and cores (one or more removal scars). In total, $n=92$ objects were classified as hammerstones ( $n=44$ raw pieces and $n=48$ cores) based on indications of impact such as crushed quartz grains, gaps of brokenout grains, and removal of the naturally weathered surfaces. Most hammerstones show only one active area (zones of crushing), but $n=13$ show traces of 2-4 active zones. 

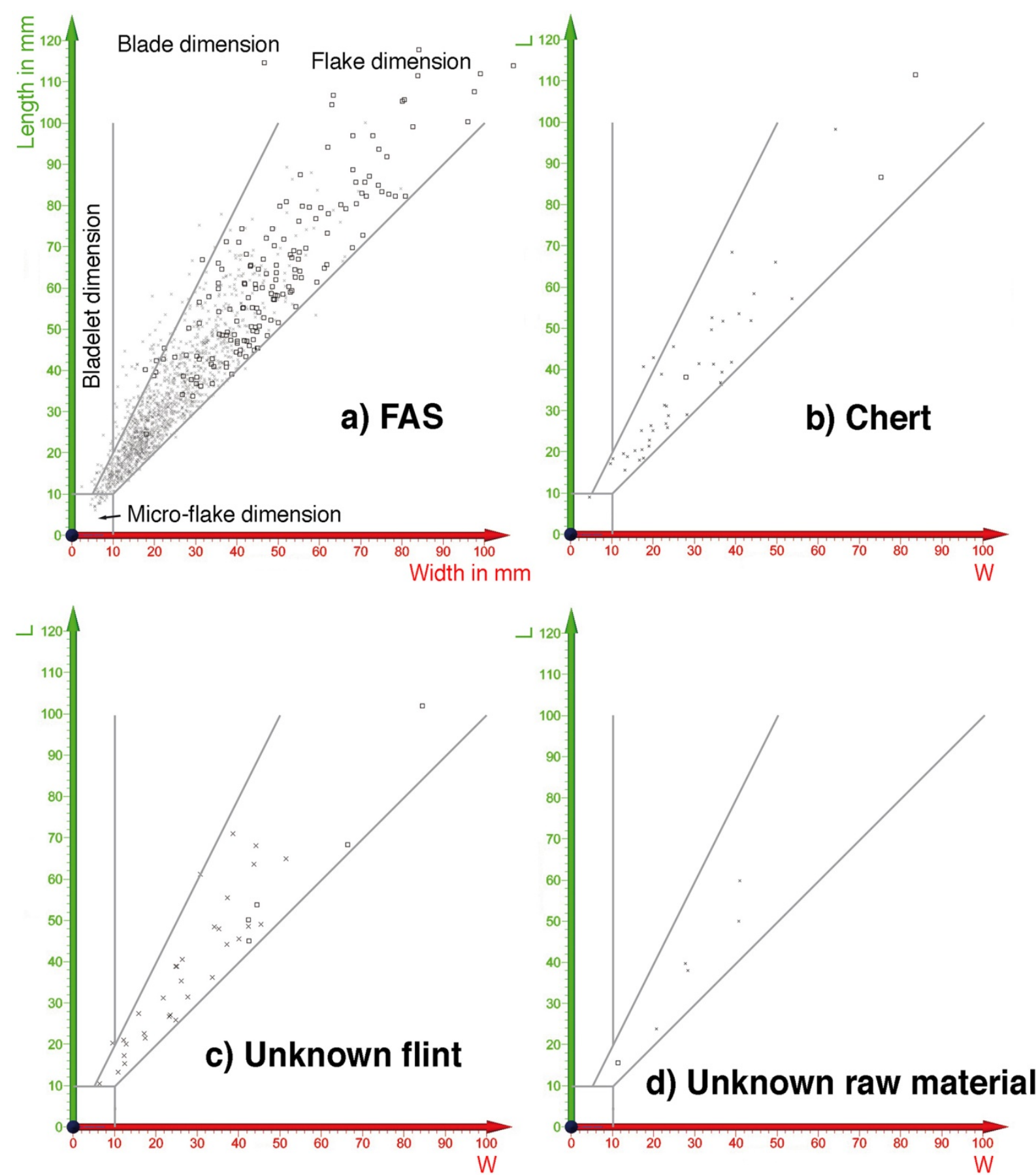

Figure 8. Dimensions (length and width) of cores and blanks from four fine-grained lithic raw materials from GH 3. Cores are displayed as squares and blanks are displayed as crosses. Only dimensions of objects are displayed that are smaller than 120 by $100 \mathrm{~mm}$. a) FAS, b) Chert, c) Unknown flint and d) Unknown siliceous raw material.

Objects ( $n=19$, see Table 6) with at least one flat surface and signs of abrasion were classified as anvils (which includes potential use as abrading stones). Some of the anvils show concave surfaces with abrasions, polished parts, small gaps of broken-out grains, or striae (see Figure 9). 
Table 5. Hammerstones from GH 3.

\begin{tabular}{lcc}
\hline Raw material & $\begin{array}{c}\text { Number of objects without } \\
\text { negatives of detachment }\end{array}$ & $\begin{array}{c}\text { Number of objects with } \\
\text { negatives of detachment }\end{array}$ \\
\hline Quartzite & 30 & 19 \\
Sandstone & 6 & 17 \\
Quarzitic sandstone & 4 & 10 \\
Quartz & 4 & 1 \\
Arkose & 0 & 1 \\
\hline Total $(\mathbf{n}=\mathbf{9 2})$ & $\mathbf{4 4}$ & $\mathbf{4 8}$ \\
\hline
\end{tabular}

Table 6. Anvils from GH 3.

\begin{tabular}{lcc}
\hline Raw material & $\begin{array}{c}\text { Number of objects without } \\
\text { negatives of detachment }\end{array}$ & $\begin{array}{c}\text { Number of objects with } \\
\text { negatives of detachment }\end{array}$ \\
\hline Quartzite & 7 & 5 \\
Sandstone & 2 & 1 \\
Quartzitic sandstone & 0 & 1 \\
Quartz & 2 & 1 \\
\hline Total (n=19) & $\mathbf{1 1}$ & $\mathbf{8}$ \\
\hline
\end{tabular}

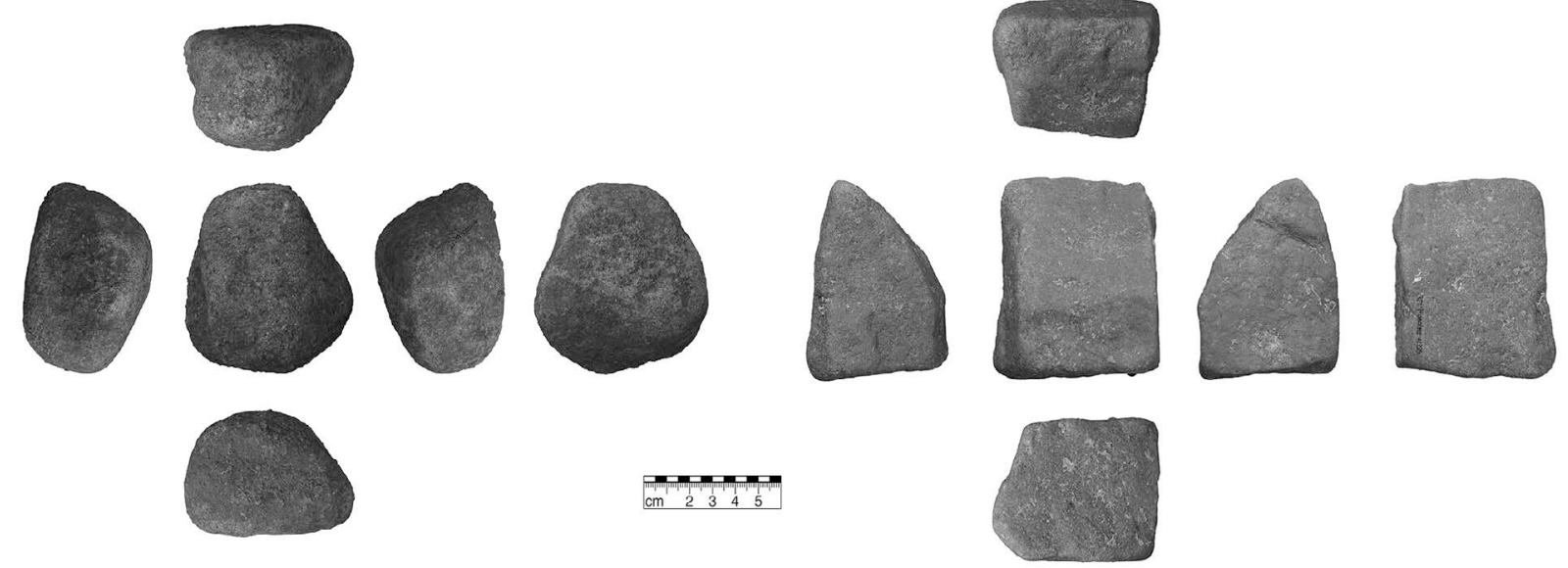

Figure 9. Example of a hammerstone and anvil. a) Hammerstone from quartzite showing bright crushing zones on rounded parts (GER10.226-058.205) and b) Anvil from quartzite showing a blocky morphology, plane surfaces and abrasion on edges (GER10.226-060.232).

\subsection{Blank-production cores}

In total, $\mathrm{n}=247$ objects classified were classified as cores (including hammerstones and anvils), however, $n=191$ served for blank-production (see Table 7). Most of these blankproduction cores are made from FAS $(n=175), n=5$ are from an unknown flint variety, and another $n=5$ are made from an unknown raw material and $n=4$ are from chert. Two objects from coarse-grained material (one from sandstone and one from quartz) were also classified as cores from blank-production. 
Table 7. Cores from GH 3 (excluding hammerstones and anvils with negatives of removal).

\begin{tabular}{|c|c|c|c|}
\hline Core class & Criteria & Number & Note \\
\hline Tested raw pieces & $\begin{array}{l}\text { Showing only some removals } \\
\text { of cortex }\end{array}$ & 57 & $\begin{array}{l}56 \text { are from FAS, one is made from } \\
\text { an unknown raw material }\end{array}$ \\
\hline $\begin{array}{l}\text { Core-preforms } \\
\text { (preforms of } \\
\text { finished } \\
\text { configured cores) }\end{array}$ & $\begin{array}{l}\text { Core was initialized, the } \\
\text { configuration started but was } \\
\text { stopped because of knapping } \\
\text { mistakes (e.g., hinges and } \\
\text { steps), no target blank } \\
\text { removed }\end{array}$ & 12 & $\begin{array}{l}\text { All are made from FAS, } n=11 \text { are } \\
\text { preforms of Levallois cores, one of } \\
\text { an pyramidal core }\end{array}$ \\
\hline $\begin{array}{l}\text { 'Opportunistic' } \\
\text { cores }\end{array}$ & $\begin{array}{l}\text { Core showing signs of surface } \\
\text { and edge configuration and } \\
\text { detachments, but could not be } \\
\text { classified further into one of } \\
\text { the other core classes, they } \\
\text { show detachments on } \\
\text { positions where it was simply } \\
\text { possible }\end{array}$ & 62 & $\begin{array}{l}58 \text { of these cores produced flakes, } \\
2 \text { produced blades and } 2 \text { bladelets; } \\
51 \text { are made from FAS, } 4 \text { are from } \\
\text { chert, one is made from an } \\
\text { unknown flint, } 4 \text { are made on } \\
\text { unknown raw material, one is from } \\
\text { Quartz, one is from Sandstone; } \\
\text { three of them are further modified } \\
\text { with a scraper retouch }\end{array}$ \\
\hline $\begin{array}{l}\text { Ventral reduction } \\
\text { cores (Kombewa } \\
\text { cores) }\end{array}$ & $\begin{array}{l}\text { Blanks showing detachments } \\
\text { of blanks on their ventral face }\end{array}$ & 10 & $\begin{array}{l}9 \text { are made from FAS and one from } \\
\text { unknown flint, two are further } \\
\text { modified with scraper retouch }\end{array}$ \\
\hline $\begin{array}{l}\text { Dorsal reduction } \\
\text { cores (Kostienki } \\
\text { cores) }\end{array}$ & $\begin{array}{l}\text { Blanks showing detachments } \\
\text { of blanks on their dorsal face }\end{array}$ & 6 & All are made from FAS \\
\hline $\begin{array}{l}\text { Bifacially reduced } \\
\text { cores-on-blanks } \\
\text { (ventrally and } \\
\text { dorsally) }\end{array}$ & $\begin{array}{l}\text { Blanks showing detachments } \\
\text { of blanks on dorsal and ventral } \\
\text { face, but independently from } \\
\text { each other) }\end{array}$ & 6 & $\begin{array}{l}\text { All are made from FAS, one is } \\
\text { further modified with a burin-blow }\end{array}$ \\
\hline Quina-like core & $\begin{array}{l}\text { Criteria following Bourguignon } \\
\text { (1997) }\end{array}$ & 1 & Made from an unknown flint \\
\hline Discoidal cores & $\begin{array}{l}\text { Criteria following Terradas } \\
\text { (2003) }\end{array}$ & 4 & $\begin{array}{l}\text { All are made from FAS, one is } \\
\text { bifacially and the others are } \\
\text { unifacially reduced; one of them is } \\
\text { made on a flake and one on a frost } \\
\text { shard }\end{array}$ \\
\hline Levallois cores & $\begin{array}{l}\text { Criteria following Boëda (1994) } \\
\text { and Van Peer (1992) }\end{array}$ & 23 & $\begin{array}{l}21 \text { are made from FAS and two } \\
\text { from chert, from them } 9 \text { are made } \\
\text { on blanks; two were further } \\
\text { modified as scraper and } \\
\text { denticulate }\end{array}$ \\
\hline $\begin{array}{l}\text { Bifacial objects } \\
\text { made on cores }\end{array}$ & $\begin{array}{l}\text { Bifacial reduction with the aim } \\
\text { to produce one or more active } \\
\text { edge }\end{array}$ & 7 & $\begin{array}{l}\text { All are made from FAS. There are } 5 \\
\text { bifacial preforms, one simple } \\
\text { Keilmesser and one Keilmesser with } \\
\text { tranchet-blow }\end{array}$ \\
\hline $\begin{array}{l}\text { Burin on frost- } \\
\text { shard }\end{array}$ & Edge removal on a frost-shard & 1 & Made from FAS \\
\hline Core-debris & $\begin{array}{l}\text { Totally exhausted and } \\
\text { destroyed core }\end{array}$ & 2 & Made from FAS \\
\hline Total & & 191 & \\
\hline
\end{tabular}


The majority of cores $(n=62)$ are opportunistic cores. These cores are characterized by successful detachments of blanks intended for further use, but show a very low degree of control of the morphology of surfaces, edges and angles. They are further classified based on the shape of the removal negatives as: flake-cores $(n=58)$, blade-cores $(n=2)$ and bladeletcores ( $n=2$, see Figure 10.c-e). The core classes of ventrally $(n=10)$, dorsally $(n=6)$ and bifacially $(n=6)$ reduced cores contains blanks with detachment negatives on either the ventral, dorsal or both faces that use the morphological defaults of the blank-core (e.g., using the convexity of the bulb, using the butt and its angle, see Figure 10.f-h). The second most abundant type $(n=57)$ is that of tested raw pieces. $(n=57)$. All of these pieces show flaws in the raw material that are very likely the reason for abandonment of the reduction process (example in Figure 10.a). Core-preforms $(n=12)$ show evidence of initialization (in terms of cortex removal and the location of adequate edge angles) and configuration (the shaping of edges and surfaces to fulfil the requirements of a litho-technological reduction concept), but in these cases, reduction was abandoned before predetermined blanks were detached (see Figure 10.b). Discoidal cores $(n=4)$ are uncommon, and aside from one bifacially-reduced core, three pieces show inclined reduction on only one surface (see Figure 10.j-k). Only a single core (Figure 10.i) is classified as Quina-like (small nodule of FAS, reduction along two inclined planes, in the sense of Turq 1989).

The Levallois cores $(n=23)$ from GH 3 have some common features. The configuration process removed only small amounts of material; zones of cortex are often left. There is evidence for preferential $(n=5)$ and recurrent $(n=18)$ blank-production. All cores have a flat matrix (disc-shaped raw piece or blank), of which $n=9$ are made on blanks. The final removals on these cores show rectangular and oval negatives and suggest the shape of the target blanks (see Table 8). From the pattern of negatives and scars on the reduction surface at maximum only two reduction cycles are visible. If negatives on the reduction surface $(>5 \mathrm{~mm}$ by $5 \mathrm{~mm}$ ) are taken into account and categorized as configuration negatives or production negatives, the maximum number of target blanks produced per core is six.

The reconstructed "standard" procedure for the reduction of Levallois cores is illustrated in Figure 11 and based on evidence from preforms, configured cores, and exhausted cores. After the selection of a flat (disc-shaped) raw piece, or less commonly a blank, cortex was removed and a platform was installed. The mostly centripetal configuration shaped the convexity of the reduction surface. Then a main platform was installed and a central blank was removed. On preferential cores, the process ends there. On recurrent cores, the reduction surface is re-configured (in a centripetal, uni-, or bidirectional manner). Two of these cores have traces of reuse, one showing a scraper retouch (after one cycle of unidirectional removal of three flakes) and another showing a denticulate retouch (after two cycles, two removals in unidirectional way and another two orthogonally to the first two removals).

Table 8. Method, negative constellation and hypothetical shape of target blank(s) on Levallois cores from GH 3.

\begin{tabular}{lccc}
\hline Method & Negative constellation & $\begin{array}{c}\text { Hypothetical shape of the target } \\
\text { blank(s) }\end{array}$ & Number \\
\hline Preferential & Uni-directional & Rectangular & 1 \\
& & Oval & 3 \\
\multirow{4}{*}{ Recurrent } & Convergent & 2 \\
& & Rectangular & 4 \\
& Unidirectional, parallel & Rectangular & 4 \\
& Bi-directional, parallel & Oval & 3 \\
& Bi-directional, orthogonal & Oval & 6 \\
\hline
\end{tabular}

Total 23 


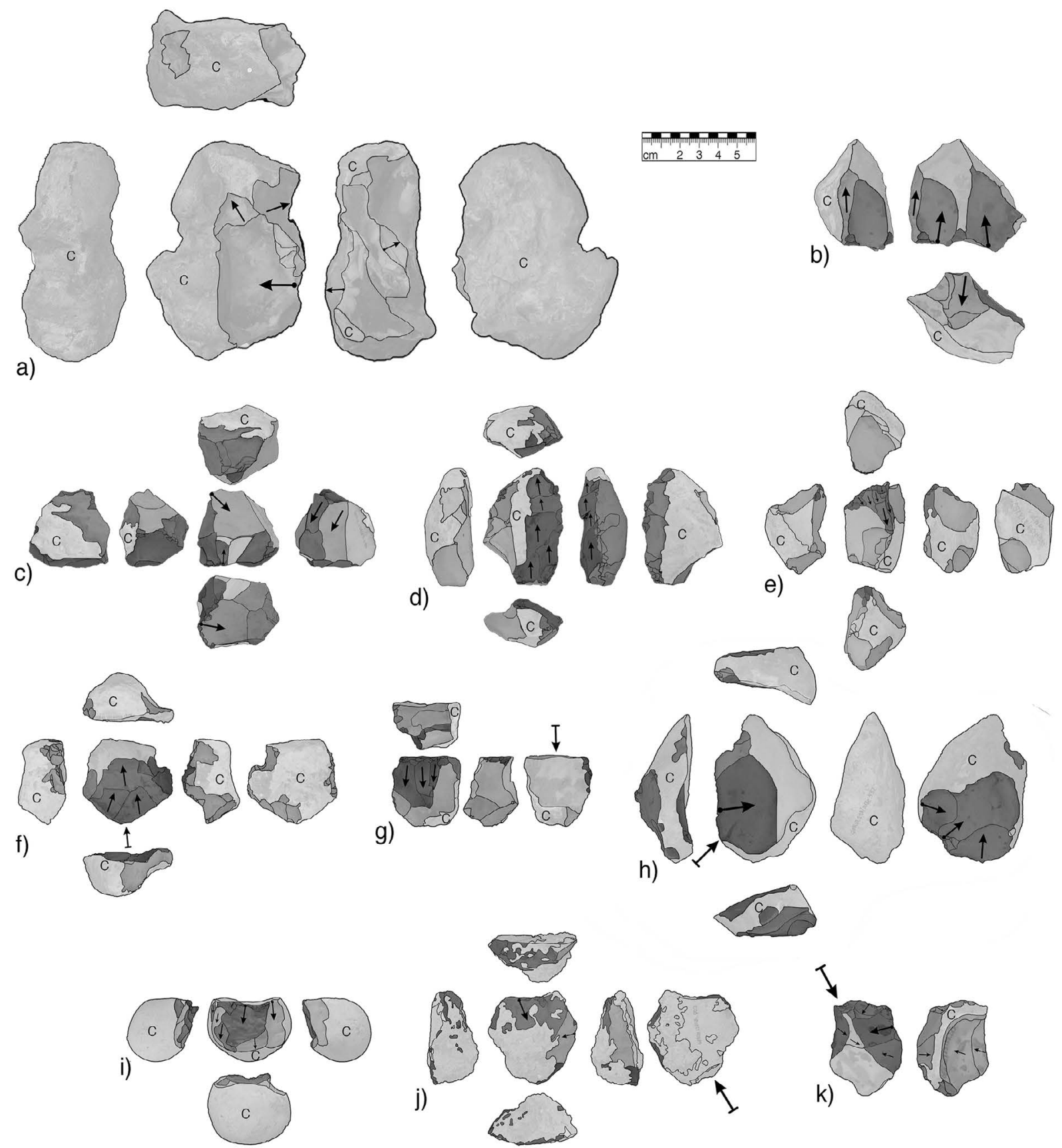

Figure 10. Examples of cores from GH 3 showing reduction sequences in grey scale (shaded to $70 \%$, all are RGB values; modern damage 255/255/255; cortex 220/220/220 (C); 1st reduction step or negative rests on former dorsal face 200/200/200; 2nd reduction step or former ventral face 170/170/170; 3rd reduction step 140/140/140; 4th reduction step 100/100/100; 5th reduction step 70/70/70; 6th reduction step 50/50/50). The diacritical scheme is following a modified version of Dauvois (1976), see also Frick \& Floss (in press). a) Tested raw piece (GER12.227-057.241); b) Core preform made from a flake (differences in patination, GER13.225058.679), reduction stopped because of hinges on the reduction surface; c) Multidirectional opportunistic flakecore (GER12.226-057.450); d) Unidirectional opportunistic blade-core on discuss-shaped raw piece showing a crested configuration (GER09.227-060.130.1); e) Opportunistic bladelet-core (GER09.227-059.147.1); f) Ventral core with reduction of the bulb part (Kombewa reduction, GER13.225-059.1254); g) Dorsal core on terminal fragment of a flake (Kostenki reduction, GER12.229-059.114); h) Bifacial core-on-blank (independently ventrally and dorsally reduced, GER10.228-058.432); i) Quina-like core (GER14.227-061.148); j) Sintered unifacial Discoidal core on dorsal surface of a blank (inclined reduction, GER09.228-060.80.3) and k) Bifacial Discoidal core on blank (inclined reduction, GER12.229-059.213). 


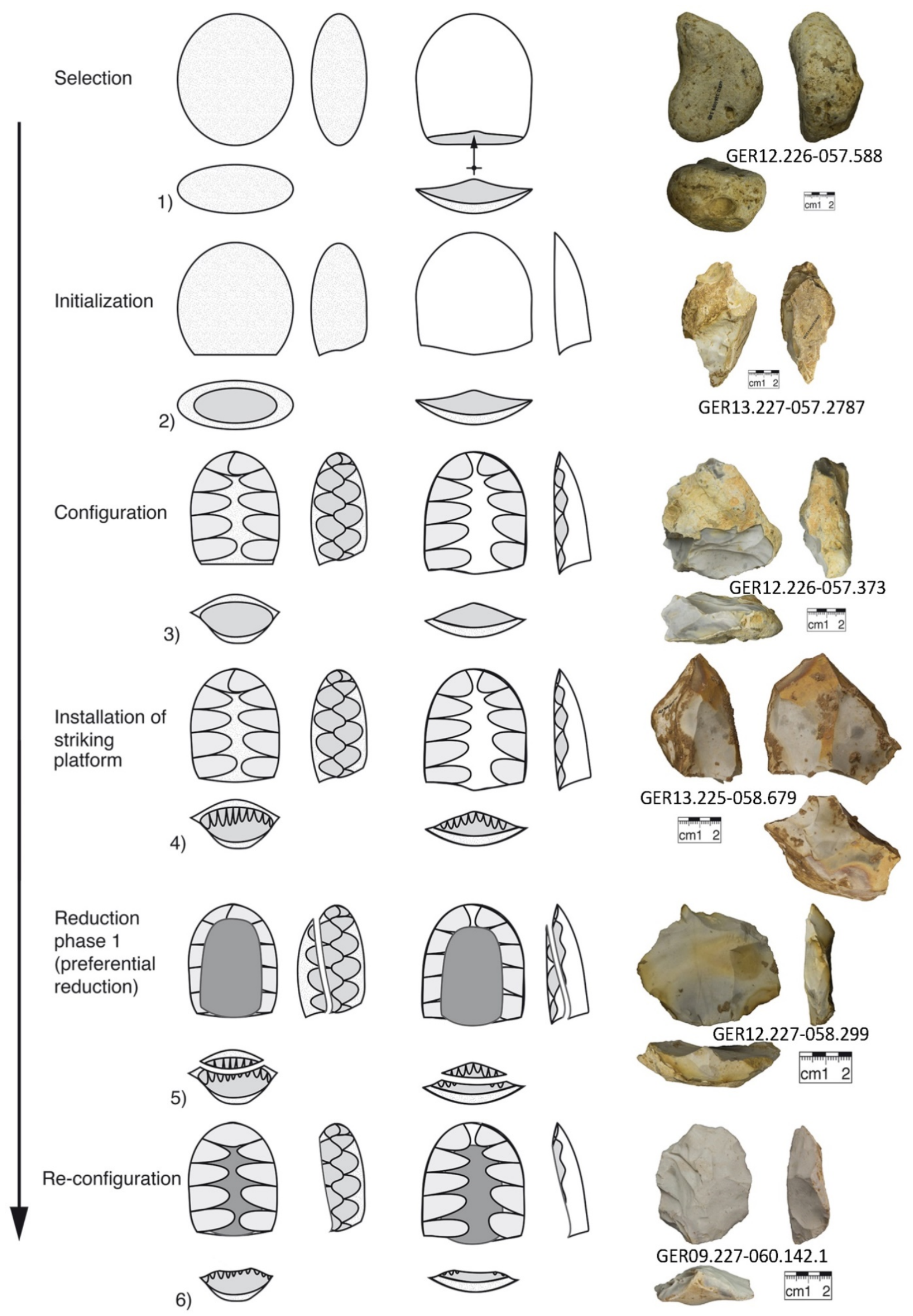

Figure 11. Constructed "standard” procedure for the reduction of Levallois cores from GH 3. Displayed as drawn synopsis (left) and illustrated with the aid of Levallois cores (preforms and exhausted cores) from GH 3 (right). (Scale bars are $2 \mathrm{~cm}$ each.) 


\subsection{Blanks}

In addition to blanks used as cores $(n=38)$, there are another $n=2205$ blanks from GH 3 that are classified as follows: $n=1889$ flakes (86\%), $n=121$ blades (5\%), $n=153$ micro-flakes (7\%) and $n=42$ bladelets (2\%) on $n=9$ types of raw material (see Table 9). The ratio of blanks from fine-grained $(n=1967)$ to coarse-grained $(n=37)$ materials is $53: 1$. In addition to the $\mathrm{n}=773$ complete blanks, there are $\mathrm{n}=1033$ blank fragments that could be further classified by type (Table 10). For $n=399$ the exact position of the fragment could not be evaluated.

Table 9. Blanks from GH 3.

\begin{tabular}{lccccc|c}
\hline & \multicolumn{5}{c|}{ Blank type } & \\
Raw material & Flake & Blade & Micro-flake & Bladelet & Total \\
\hline FAS & 1589 & 110 & 136 & 40 & 1875 \\
Unknown flint & 39 & 3 & 0 & 0 & 42 \\
Chert & 43 & 6 & 3 & 1 & 53 \\
Lacustrine flint & 4 & 0 & 0 & 0 & 4 \\
Quartzite & 19 & 0 & 0 & 0 & 19 \\
Quartzitic sandstone & 4 & 0 & 0 & 0 & 4 \\
Quartz & 14 & 0 & 0 & 0 & 14 \\
Sandstone & 7 & 0 & 0 & 0 & 7 \\
Unknown lithic raw material & 172 & 2 & 12 & 1 & 187 \\
\hline Total & & & & & $\mathbf{2 2 0 5}$ \\
\hline
\end{tabular}

Table 10. Numbers of unmodified and modified blanks per blank class (without cores-on-blanks).

\begin{tabular}{llll}
\hline Blank class & Unmodified & Modified & Total \\
\hline Simple blank & 841 & 187 & 1028 \\
Raw-piece cap & 199 & 29 & 228 \\
Blank deriving from hammerstone or anvil & 27 & 0 & 27 \\
Blank of surface correction & 347 & 32 & 379 \\
Blank of edge correction & 205 & 14 & 219 \\
Crested blank & 5 & 1 & 6 \\
Éclat and lame débordant(e) & 36 & 14 & 50 \\
Core tablet & 1 & 1 & 2 \\
Levallois blank & 62 & 94 & 156 \\
Ventral blank (Kombewa blank) & 11 & 2 & 13 \\
Tranchet-blow blank & 9 & 0 & 9 \\
Bifacial object on blank & 0 & 19 & 19 \\
Blank deriving from retouch & 68 & 1 & 69 \\
Total & $\mathbf{1 8 1 1}$ & $\mathbf{3 9 4}$ & $\mathbf{2 2 0 5}$ \\
\hline
\end{tabular}

Despite the fact that only two refits could have been made with coarse-grained objects (example in Figure 7), it is very likely that the majority of these blanks derive from used hammerstones and anvils (crushed zones on the surfaces of the blanks).

Concerning the used technique for the blank production, it could be evaluated that $\mathrm{n}=1124$ were made using direct-hard-straight technique, $\mathrm{n}=124$ using direct-soft-tangential technique and $n=2$ show evidences of bipolar technique (for $n=955$ it could not be evaluated, because of fragmentation or crushing). 
Over all, $\mathrm{n}=13$ black classes could be evaluated. They are listed in Table 10 and show the diversity. Nearly all blank-classes contain pieces that were modified after production (except tranchet-blow blanks). Raw-piece caps are blanks with complete or almost complete cortex cover and are the first do be removed on raw pieces. Correction blanks can have cortex on the dorsal surface or butt. They are separated in blanks removed to shape a surface and blanks that only affected an edge of a core. Two other classes show prominent scars on the dorsal surface and are separated from their symmetry in cross section (symmetrical - crested blanks, asymmetrical - éclats and lames débordant(e)s). Blanks for the rejuvenation of core platforms are seldom, which is surprising as this working step is visible in Levallois cores, but is seems that core platforms are renewed in removing blanks that fall into correction blank classes. Levallois blanks (in the sense of target blanks) are classified from their shape (Van Peer 1992) and often have a faceting on the butt (examples in Figure 12). These blanks use the convexity of the core's reduction surface and do not produce them. In a typological separation into Levallois flakes $(n=114)$, blades $(n=18)$ and points $(n=24)$, flakes are dominant. The analysis of direction and constellation of dorsal negatives on these blanks show a diverse picture. The negative pattern of $n=131$ could be evaluated and show that $n=78$ blanks having a unidirectional pattern, $n=29$ a bidirectional pattern and $n=24$ a centripetal pattern.
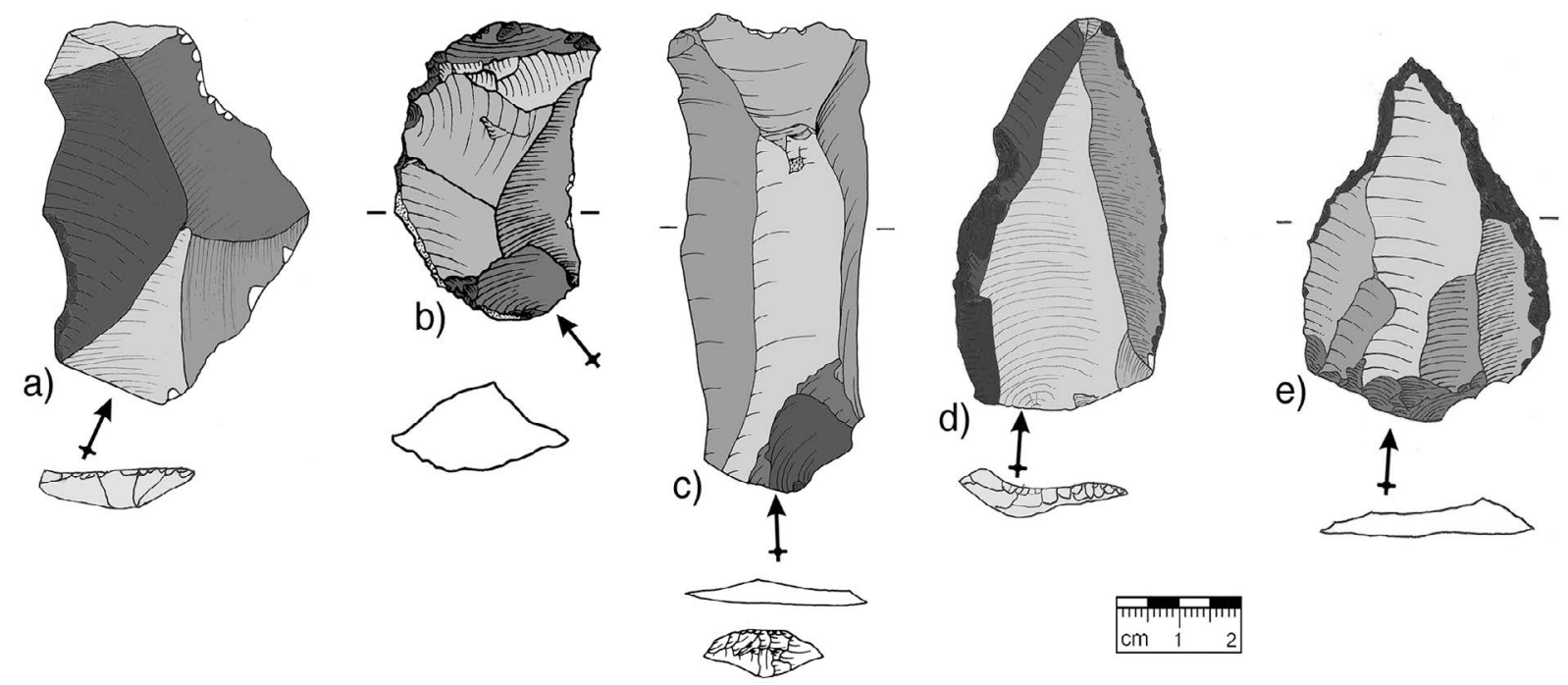

Figure 12: Examples of Levallois blanks from GH 3 (for grey scale see explanation for Figure 10). a) Levallois flake (GER10.227-058.336), b) Éclat débordant (GER12.225-058.268), c) Levallois blade (GER11.225-060.61), d) Marginal retouched Levallois point (GER10.226-059.261) and e) Constructed (retouched) point on Levallois flake (GER12.226-057.1200). The different grey shades correspond to subsequent reduction steps (the darker the younger, see Frick \& Floss in press for a detailed description).

In total, there are $n=13$ blanks deriving from ventral reduction on blanks (Kombewa). Most of them removed a quite flat part of the ventral surface. Despite the fact that some bulb removal negatives on other flakes could be detected, there are no real Janus flakes present.

Tranchet-blow blanks (TBBs) are also present (which is not surprising as Keilmesser with tranchet-blow negative are also present in GH 3) and can be separated into $n=5$ primary (initial) and $n=4$ secondary (consecutive) TBBs ( $n=2$ right sided and $n=7$ left sided). Additionally, there are $n=69$ blanks deriving from retouch (flaking direction equals the retouch direction).

The diversity of blank classes shows that every stage of lithic reduction is present inside GH 3 (decortication, configuration of cores, reduction of cores, rejuvenation of cores, production and re-confection of bifacial objects, as well as the retouch of blanks). 


\subsection{Modified objects}

In addition to modified blanks ( $n=394)$, there are $n=18$ other modified objects from cores $(n=12)$ and frost shards $(n=6)$. These $n=412$ modified objects represent around $10.93 \%$ of the entire lithic assemblage of GH 3. If only blanks are taken into account, the modified blanks represent around $17.87 \%$ and if only fine-grained raw materials are counted $(n=1974)$ the $\mathrm{n}=384$ modified blanks represent around $19.45 \%$ of these raw materials (see Table 11 ).

At least $n=18$ distinct types of modification could be identified. Some are quite rare, such as the bipolar modification on a splintered piece $(n=1)$, the transformation of an irregular nodule into a sort of "bowl" with a handle (containing a yet unknown black substance), heavily-modified Moustier points $(n=2)$, and $n=3$ circumferentially retouched blanks (known as Groszaki). Borer modification and burin blows are also rare (each $n=5$ ), as are tranchet blows $(n=6)$. Other modifications are more common, but not abundant: bifacial objects $(n=26)$, denticulated retouch $(n=18)$, notches $(n=14)$, straight truncation $(n=16)$, end scraper retouch $(n=25)$, and pointed retouch $(n=22)$. More frequent modifications include undiagnostic retouch (partial retouch that could not be further classified, $n=38$ ), knife backing $(n=41)$, and simple lateral retouch $(n=46)$. Two types of modification are particularly abundant: side-scraper retouch $(n=92)$ and modification that could be related to hafting purposes $(n=106)$. In all, there are $n=412$ objects showing $n=467$ zones of retouch. Objects showing multiple modifications include combinations of scraper-retouch and burin blows, scraper retouch with tranchet-blows, or scraper- and denticulated- retouch in combination. Evidence for tranchet-blow negatives is present (aside from on the Keilmesser) on a lame débordante, a backed knife, a side scraper, and a ventral flake. There is also evidence for modification on blanks $(\mathrm{n}=12)$ in multiple phases (resulting in intensive changes in the morphology of these objects), but due to extensive patination of the surfaces, both recycling (with a gap in time) and immediate reuse (immediately) are possible (see Figure 13).

Table 11. Numbers of modification types on lithic objects from GH 3

\begin{tabular}{lcccc}
\hline Type of modification & $\begin{array}{c}\text { Made on } \\
\text { core }\end{array}$ & $\begin{array}{c}\text { Made on } \\
\text { blank }\end{array}$ & $\begin{array}{c}\text { Made on } \\
\text { frost shard }\end{array}$ & Total \\
\hline Splintered piece & 0 & 1 & 0 & 1 \\
Bifacial object & 3 & 19 & 4 & 26 \\
Borer & 0 & 5 & 0 & 5 \\
Hafting rest & 0 & 106 & 0 & 106 \\
Denticulate (toothed retouch) & 0 & 18 & 0 & 18 \\
Notch & 0 & 14 & 0 & 14 \\
Truncation & 0 & 16 & 0 & 16 \\
Lateral retouch (minimal invasive retouch) & 0 & 46 & 0 & 46 \\
Knife backing & 0 & 41 & 0 & 41 \\
Side-scraper retouch (heavily invasive retouch) & 6 & 85 & 1 & 92 \\
Burin blow & 0 & 4 & 1 & 5 \\
End-scraper retouch & 0 & 25 & 0 & 25 \\
Trachnet-blow & 1 & 5 & 0 & 6 \\
Moustier point & 0 & 2 & 0 & 2 \\
Bowl with handle & 1 & 0 & 0 & 1 \\
Groszak & 0 & 3 & 0 & 3 \\
Retouched point (retouch led to convergent, & 0 & 22 & 0 & 22 \\
$\quad$ pointed retouch) & & & & \\
Simply retouched (retouch to insignificant for clear & 0 & 38 & 0 & 38 \\
$\quad$ classification) & & & & \\
\hline Total & $\mathbf{1 1}$ & $\mathbf{4 5 0}$ & $\mathbf{6}$ & $\mathbf{4 6 7}$ \\
\hline
\end{tabular}




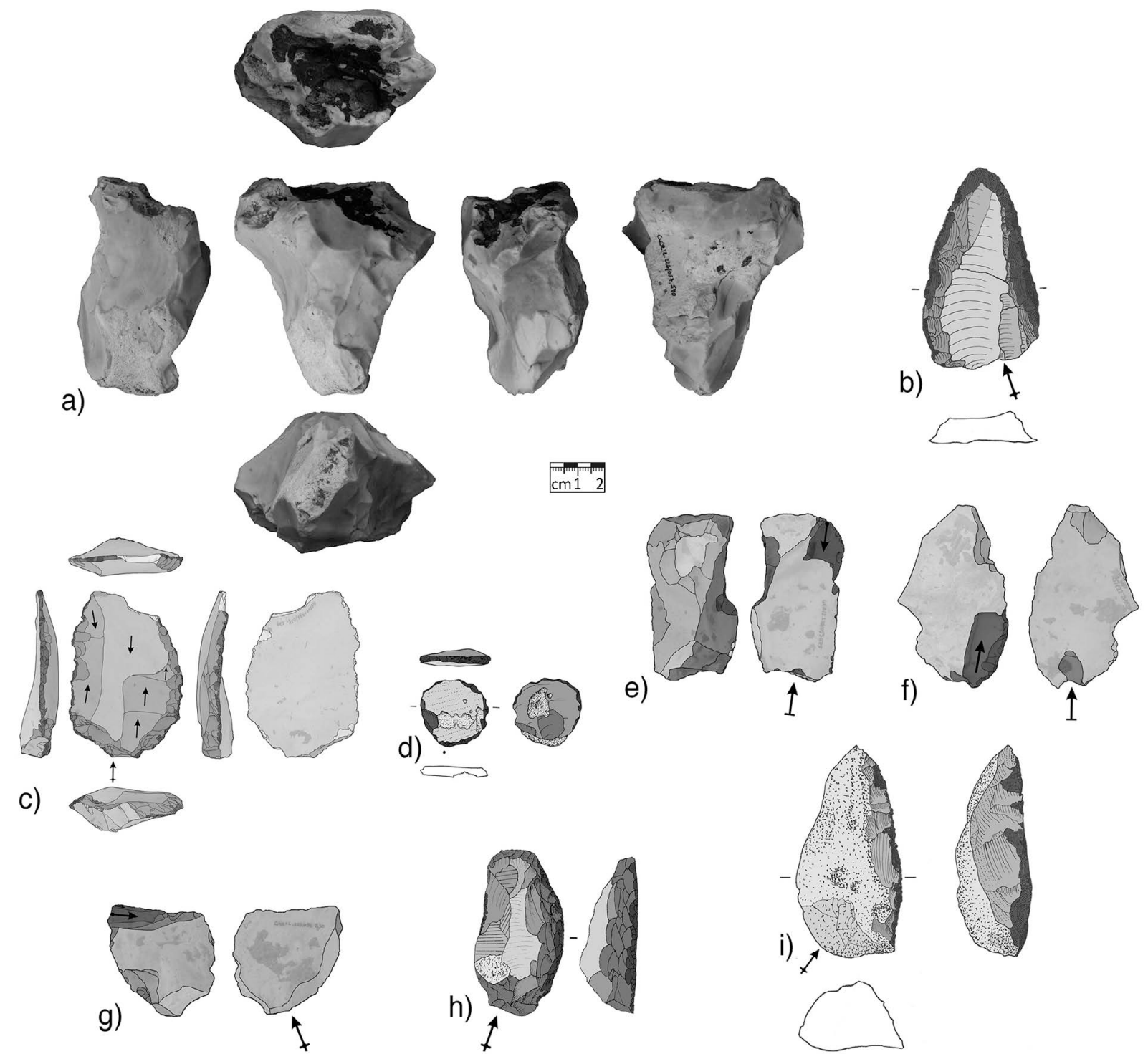

Figure 13. Examples of modified objects from GH 3. a) Bowl with handle and unknown black substance in concavity (GER12.226-057.540), b) Levallois flakes with intensive and invasive multiphase retouch and rounded terminal end (GER12.229-059.637), c) Levallois flake with broken out tip and tow phase retouch (GER10.226-058.239), d) Groszaki (GER11.225-059.191), e) Lame débordante with tranchet-blow negative on ventral surface (GER12.229-059.585); f) Cortical flake with tranchet-blow negative and marginal retouch (GER12.227-057.689), g) Terminally broken ventral flake with two tranchet-blow negatives (GER12.229059.530), h) Side scrapers with steeply and invasively multiphase retouch on thick flake (GER12.226-057.294) and i) Cortical flake with multiphase retouch GER10.226-058.89). For grey shades see explanation for Figure 10.

\subsection{Bifacial objects}

In the lithic assemblage from GH 3, there are $n=27$ bifacial objects (see examples in Figure 14), further sub-divided into six groups (see Table 12). Aside from $n=8$ bifacial preforms (pre-products or semi-finished objects) showing partial bifacial reduction but lacking a clear edge or surface regularization, there are $n=5$ asymmetrical bifacial objects with restricted backing along their perimeter, and $n=2$ symmetrical bifacial objects with planoconvex surfaces. Keilmesser (asymmetrically bifacially backed knives) are present in two varieties [simple Keilmesser with a back opposing the cutting-edge and wedge-shaped crosssection $(n=4)$, and Keilmesser modified with tranchet-blow negatives $(n=3)]$. Additionally, 
there are $n=5$ artifacts classified as bifacially worked objects (with one bifacially modified cutting-edge, or one edge is ventrally and the other is dorsally modified)
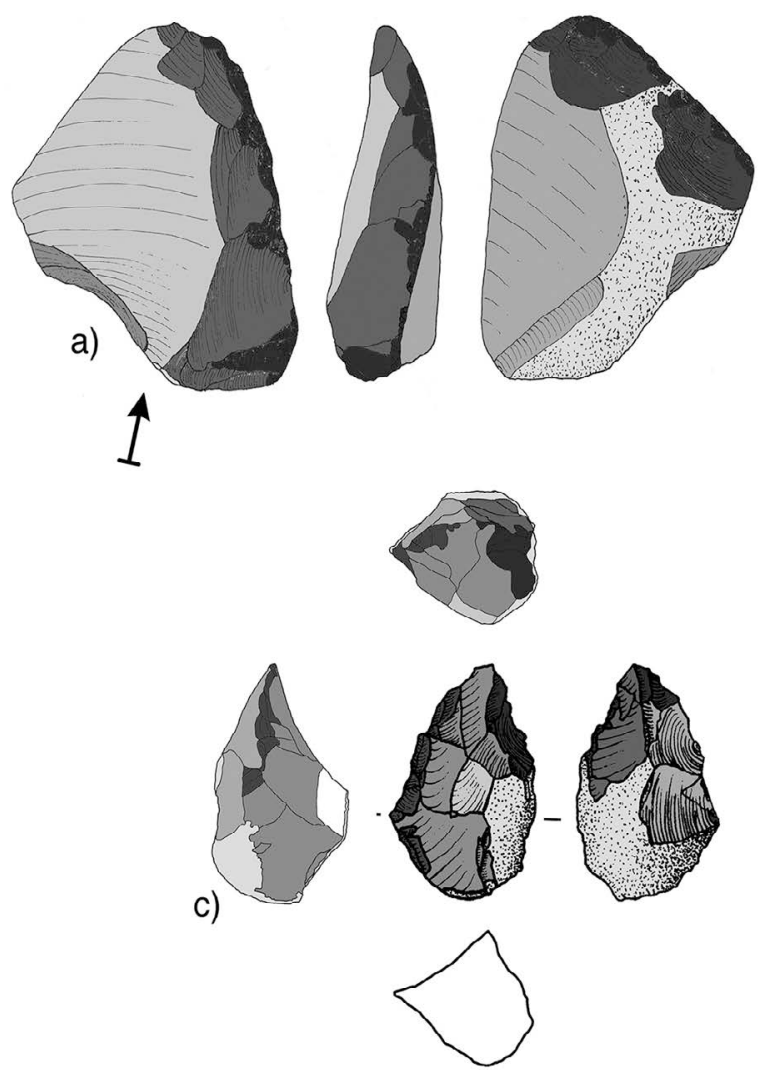
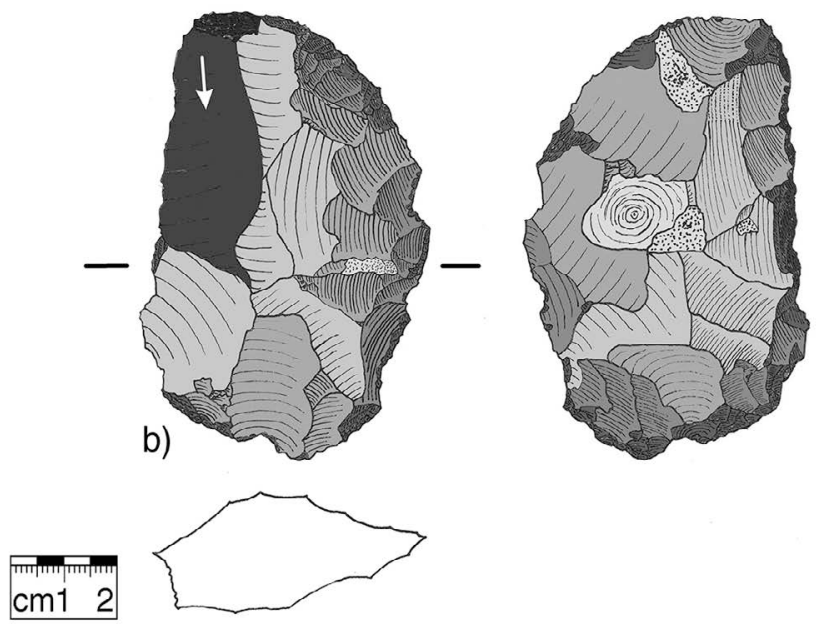

d)
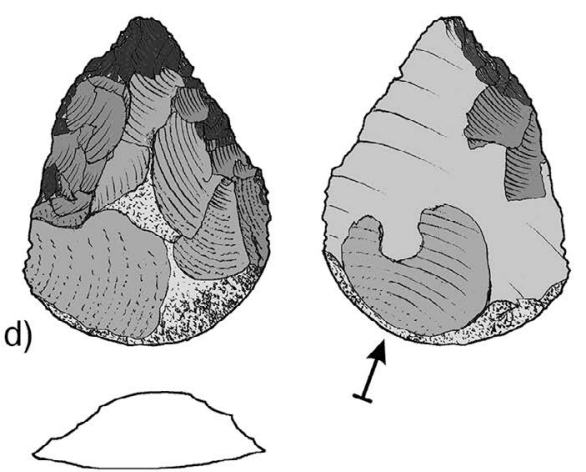

Figure 14. Examples of bifacial objects from GH 3. a) Bifacially worked object with two independent active edges (GER10.226-059.196), b) Keilmesser with tranchet-blow negative (GER12.229-059.428), c) Small symmetrical biface with two plane-to-convex surfaces (GER12.227-057.420) and d) Symmetrical bifacial object with plano-convex cross section and plane-to-convex surfaces (GER13.227-057.1790). For grey shades see explanation for Figure 10.

Table 12. Bifacial objects of GH 3.

\begin{tabular}{lll}
\hline Bifacial object & Matrix & Total \\
\hline Bifacial preform & Core & 2 \\
Bifacial preform & Blank & 3 \\
Bifacial preform & Frost shard & 3 \\
$\begin{array}{l}\text { Asymmetric bifacial object with restricted backing } \\
\text { Symmetrical bifacial object with plano-convex cross section and }\end{array}$ & Blank & 5 \\
$\begin{array}{l}\text { plane-to-convex surface } \\
\text { Asymmetrically bifacially backed knife (simple Keilmesser) }\end{array}$ & 2 \\
$\begin{array}{l}\text { Asymmetrically bifacially backed knife (simple Keilmesser) } \\
\text { Asymmetrically bifacially backed knife with tranchet-blow negative(s), }\end{array}$ & Core & 3 \\
$\begin{array}{l}\text { Keilmesser with tranchet blow } \\
\text { Asymmetrically bifacially backed knife with tranchet-blow negative(s), } \\
\text { Keilmesser with tranchet blow }\end{array}$ & Blank \\
Bifacially worked object & & 2 \\
\hline Total & Blank & \\
\hline
\end{tabular}


The analyses of bifacial objects from VP I and II are described in Frick and Floss (in press) and are therefore abbreviated in this context. Despite the morphological diversity of these bifacial objects, there are some common features evident in the production sequences. Following the selection of a suitable matrix, a back is installed to facilitate shaping of opposing plano-convex surfaces. Alternatively, single surfaces are frequently shaped in a plane-to-convex way (one surface is flat in one part and convex in another) following installation of the backed edge. The confection of cutting-edges is always done with so called alternating unidirectional edge regularization (wechselseitig gleichgerichtete Kantenbearbeitung, after Bosinski 1967) and is related to specific rotation processes on two axes during production (see Weißmüller 1995; Frick \& Floss in press).

\section{Discussion and conclusions}

\subsection{GH3 at VP II}

The lithic assemblage of GH 3 shows different strategies of resource use with regard to coarse-grained and fine-grained lithic raw materials, including: the testing of raw pieces, the configuration of cores, the production of blanks, the modification of objects, and use as hammerstones and anvils. Fine-grained materials are present in all stages of lithic reduction (from the import of complete raw pieces to the discard of extensively modified blanks), whereas coarse-grained materials served as anvils (maybe for breaking bones as first faunal studies suggest, see Wilk 2014a; b) or hammerstones, as indicated by the presence of detached blanks and shattered or crushed zones on such artifacts. Despite extensive attempts at lithic refitting, only a very small number of refits could be made. Based on this fact and on observations of the site, we hypothesize that the central zone of the occupation surface has not yet been excavated.

The presence of complete and tested raw pieces from local raw material is strong evidence for local procurement of raw materials and for on-site transformation. This is supported by the studies of lithic raw-material sourcing, which indicates potential sources as near as around $150 \mathrm{~m}$ from the site. The majority of lithic objects are made from such local materials and reveal a high level of familiarity with the territory (materials from on top of the hill ranges, and from the neighbouring valleys or creeks). Intensively worked objects are predominantly made on these materials. The presence of exogenous lithic raw materials (very likely lacustrine flint, distance around 100 to $120 \mathrm{~km}$ ) is evidence for a connection into northeastern direction.

This rather unique combination of prevalent Levallois reduction, Groszaki, the wide range of bifacial objects (including Keilmesser), and tranchet-blow modification of the assemblage of GH 3 at VP II is very likely situated in the context of the early OIS 3 (Heckel et al. 2016; Richard et al. 2016; Zöller \& Schmidt 2016). Congruent observations of lithic features on further assemblages from the Côte chalonnaise and surrounding (e.g., Farizy 1995; Herkert et al. 2015; Frick \& Floss in press) led to the assumption that VP II and its (preliminarily dated) recently-excavated stratified units can serve as point of reference for the classification of similar assemblages in the immediate area (Frick et al. 2016; Frick 2016b).

In previous assessments, following the descriptions of Desbrosse et al. (1976) of the collection Jeannin from the Méray excavation in 1868 (Méray 1869; 1876), Richter (1997) and Jöris (2003) included the assemblage of Keilmesser with tranchet blow from the nearby VP I into their definition of the Mousterian with Micoquian-Option (MMO) or Keilmessergruppen (KMG) and probably followed the description of Desbrosse et al. (1976) that Prondniks are frequently associated with Quina retouch. Richter (1997: 243) integrated the finds from VP I into the MMO-A (older Micoquian) and explained that - following the stratigraphy of Sesselfelsgrotte G - such finds are associated with non-Levallois industries. In 
a similar manner, Jöris (2003: 107) set the assemblage of VP I (also using the description of Desbrosse et al. 1976) into the KMG-B(2) that are characterized by the marginality of Levallois reduction, missing of systematized production of blanks, rare presence of bifaces and dominance of Keilmesser.

\subsection{Multiple definitions of the term "Micoquian"}

We are following the description of Veil et al. (1994) in using the term Keilmessergruppen ("Micoquian” sensu Bosinski, Günther, Toepfer, Valoch), that was first used by Mania (1990: 144-148) and preferred by Veil et al. (1994) or Jöris (2001; 2003). Bosinski (1967) included in his definition of the central European bifacial assemblages clearly the reference to La Micoque layer N(6) of Peyrony's (1938) excavation in 1929. He later adopted the term Keilmessergruppen (Los grupos Keilmesser) in an overview of the Middle Palaeolithic of central Europe (Bosinski 2001).

However, the affiliation of the assemblage of GH 3 with congruent assemblages to the Keilmessergruppen leads to questions about definition and extension of these cultural entities, prevalently in its association with the term "Micoquian" and its varying definitions.

The term "Micoquian" established by Hauser (1916) for all assemblages at La Micoque hundred years ago, was later reduced by Breuil (1932a) and only used for layer N(6) of Peyrony’s excavation from 1929 (Peyrony 1938).

In the following, in 1944, Benet-Tygel (1944) suggested in an overview of the Palaeolithic in Poland that the La Micoque industry from the Riss-Würm (warm climate) in western Europe evolved into similar industries in Poland in the Würm I (cold climate). She also mentioned remarkable similarities to Russian industries from Kiik Koba or Kostenki.

In the 1950s, the term "Micoquian" was used in Germany for bifacial industries of the Middle Palaeolithic (e.g., Zotz 1951). In particular, Bosinski (1967; 1970a) used the term "Micoquian" for bifacial industries from central Europe that show a strong connection to the industry of la Peyrony's La Micoque N(6). In the same direction as Bosinski, Chimielewski (1969) used the term Micoquo-Prodnikien for industries in central Europe, an emphasis of the Prondnik cycle (dynamic reduction of particular Keilmesser from Ciemna cave) of Krukowski (1939-1948).

In France instead, the term "Micoquian" was connected, following the definition of Breuil (1932a; 1932b) to particular late Acheulian industries (Bordes 1954; Blanchard 1963; Bordes 1984) because of the presence of bifaces similar to Micoquekeile as known from La Micoque N(6) of Peyrony's excavation.

But it need to be noted that Bordes (1984: 54) pointed also out that with the exception of differences in bifacial forms there are almost no differences between the MTA and the Micoquian: "Il découlé de l'étude de ces quatre gisements micoquiens que l'outillage sur éclats ne se différencie de celui que nous verrons dans le Moustérien de tradition acheuléenne que par des nuances ...”. The evolutionary line that has been supposed to connect the Acheulian with the "Micoquien" (Breuil 1932a) was reformulated some years ago (see e.g., Gouédo 1999).

Rosendahl (2004; 2006; 2011) revived recently the strong similarities, as noted by Bosinski (1967; 1970a), of the upper levels at la Micoque (N-P) with the Keilmessergruppen from central Europe, but objected that the missing chronological fixation of the upper levels of La Micoque makes it idle to question the connection. For her the term "Micoquian" "can presently only be considered as a classification category." (Rosendahl 2011: 133). Unfortunately, the destroyed upper levels at La Micoque still remain undated (Falguères et al. 1997; Rosendahl 2004). 
Depaepe (2014) separates the Central and Eastern European "Micoquian" into two groups. A first phase (Keilmessergruppen) between 60 and $40 \mathrm{ka} \mathrm{BP}$ and a subsequent second phase (Blattspitzengruppen). The attempt of connecting assemblages of the Blattspitzengruppen (Szeletian sensu lato) with Late Middle Palaeolithic assemblages in Eastern France can be noted. For instance, Pouliquen (1982a; 1982b; 1983) saw similarities of the surface collection finds from Saint-Martin-sous-Montaigu (Saône-et-Loire) with foliated pieces (Blattspitzen) from the Altmühlgruppe (Altmühlian). Similarly to this approach, site from the northern margin of the Bresse basin are discussed in using comparisons with finds denominated as Blattspitzen from the Blattspitzenkomplex of Bavaria (Lamotte et al. 2005; Lamotte et al. 2012; Lamotte et al. 2014; Lamotte et al. in press). Other scholars see the Blattspitzengruppe as independent from the Keilmessergruppen and as final stage of the Middle Palaeolithic in southern Germany and eastwards (Bolus \& Conard 2001; Conard \& Bolus 2003; Bolus 2004).

In a coarse review of the literature three chronological entities are often called "Micoquian" in France (for the tripartite division see also Blaser \& Chaussé 2016). At first the presence of bifacial objects similar to Micoquekeile in assemblages of presumed RissWürm (now Eemian interglacical) or Saalian (OIS 6 and earlier) age from the Paris basin that are used by Breuil (1932a), as well as Bordes (1954). A second entity is situated in the Sennonais (Dept. Yonne) in the beginning of the Würm in the OIS 5c and 5d (e.g., Deloze et al. 1994) and another entity is present in sites such as Champlost in the OIS 4 to 3 (Farizy 1985; 1988; 1994; 1995). The sites of Grottes de la Verpillière I and II are most likely situated in this later time range, too.

As shortly demonstrated by these examples, different entities with differences in time, as well as spatial position are sharing the same name. In that sense we almost agree with Blaser \& Chaussé (2016: 14): "It would nonetheless be advisable, following the example of the German works, to abandon the term Micoquian, and to find a new name to denote this archeological entity." We can add to find names because of these at least three clearly detectable differences in time and spatial position.

The term Keilmessergruppen is used by Jöris (2003) in a chrono-stratigraphical and chrono-cultural sense, sorting the entities that almost correspond to them defined by Bosinski (1967) and defining three or six groups (A1-A2-B1-B2-C1-C2).

If the preliminary radiometric dating of VP II, GH 3 (Heckel et al. 2016; Richard et al. 2016; Zöller \& Schmidt 2016) is reliable and surrounding sites are also situated in the same chronological stage (but as previously noted they are decontextualized, i.e. material from surface collections and from badly documented ancient excavations) it would be plausible to define a site cluster of Keilmesser-bearing sites in the Côte chalonnaise.

This paper does not have the aim to solve this European "Micoquian" dilemma in the classification of the Middle Paleolithic record, but it contributes to the discussion of Middle Palaeolithic entities that do not fit into classification systems established in the mid of the $20^{\text {th }}$ century.

The present paper, as well as further studies (Frick 2010; Frick \& Floss 2015; in press; Frick 2016b) contribute to demonstrate that Levallois is crucial for the production of blanks in both sites (VP I and II). Showing a high diversity, bifacial objects are prevalently characterized by the presence of similarities in production and shape and constellation of surfaces and edges. A tranchet-blow technique is occasional used for getting sharp, acute actives edges on Keilmesser and sometime other objects (Frick \& Floss in press). These features (and others that are currently under research) make it very likely to formulate a clustered group of Middle Palaeolithic assemblages from the Côte chalonnaise and its surrounding (Frick et al. 2016). 
This assessment is supported by the new materials and analyses from the intact sediments of GH 3 at VPII, as demonstrated in the current article.

\section{Acknowledgements}

Many thanks are due to $\mathrm{H}$. Floss for the approving the publication of this study as a stand-alone article. The analyses are part of the author's dissertation research. M. Siegeris, K. Herkert and $\mathrm{H}$. Floss have contributed to the identification of the raw materials. S. P. Steigerwald deserves thanks for her help in figure preparation. Sincere thanks also to the working group under the direction of H. Floss (namely, K. Herkert, Ch. Th. Hoyer, M. Siegeris, N. Huber, S. P. Steigerwald, H. Würschem and R. Litzenberg) for all the support and data collection in the field, in the lab, and from collections (university, museum and private). The analysis of all the material would not be possible without the enormous efforts of the entire research team at VP II all the years.

This analysis is financially supported by the project FL 244/5-1 of the Deutsche Forschungsgemeinschaft (DFG), the PCR (Projet Collectif de Recherche) UMR 6298 ARTeHIS "Le Paléolithique supérieur ancien en Bourgogne méridionale" at Dijon and the CRC 1070 B01 (RessoursenKulturen, Lithic raw materials between Burgundy and the Swabian Jura) at Tübingen. The Service Régional d'Archéologie (S.R.A) of Burgundy supported excavations at VP II, with the additional support of the Mairie de Mellecey. A cordial thanks goes to $\mathrm{C}$. Heckel for her great support and for improvements to the original version of this manuscript, including language and grammar correction. Furthermore, I would like to extend sincere thanks to the editors and anonymous reviewers of this paper, whose suggestions helped to transform the initial manuscript into a paper worthy of publication.

\section{References}

Benet-Tygel, S. 1944, The Paleolithic Period in Poland. American Anthropologist, 46(3): 292316. doi:10.1525/aa.1944.46.3.02a00020

Blanchard, J. 1963, Bifaces Micoquiens (La Micoque et Bellême). Bulletin de la Société Préhistorique de France, 60(1): 48-56. (in French) ("Micoquian Bifaces (La Micoque and Bellême)”). doi:10.3406/bspf.1963.3880

Blaser, F. \& Chaussé, C. 2016, Saint-Illiers-la-Ville and the Micoquian of Weichselian sequences of the Paris Basin. Quaternary International, 411: 163-178. doi:10.1016/j.quaint.2015.06.035

Boëda, É. 1994, Le concept Levallois, Variabilité des Méthodes. Monographie du Centre de Recherches Archéologiques Vol. 9. CNRS Éditions, Paris, 273 p. (in French) ("The Levallois Concept, Variability of Methods”)

Bolus, M. 2004, Settlement Analysis of Sites of the Blattspitzen Complex in Central Europe. In: Settlement Dynamics of the Middle Paleolithic and Middle Stone Age, Vol. 2 (Conard, N.J., Ed.), Kerns Verlag, Tübingen: p. 201-226.

Bolus, M. \& Conard, N.J. 2001, The Late Middle Paleolithic and Earliest Upper Paleolithic in Central Europe and their Relevance for the Out of Africa Hypothesis. Quaternary International, 75(1): 29-40. doi:10.1016/s1040-6182(00)00075-6 
Bons, P. \& Wißing, C. 2009, Aspects of local geological structure in connection with the palaeolithic cave site in Germolles (Commune de Mellecey, France). In: Rapport de fouille programmée. Lieu-dit: Les Grottes de La Verpillière I et II à Germolles (Floss, H., Ed.), Abteilung für Ältere Urgeschichte und Quartärökologie, Service Régional d'Archéologie Bourgogne, Tübingen, Dijon: p. 1-11.

Bordes, F. 1953, Essai de Classification des industries "moustériennes”. Bulletin de la Société Préhistorique de France, 50(7/8): 457-466. (in French) ("Essays of Classification of “Mousterian” Industries”). doi:10.3406/bspf.1953.5156

Bordes, F. 1954, Les limons quaternaires du Bassin de la Seine. Stratigraphie et archéologie paléolithique. Archives de l'Institut de paléontologie humaine Vol. 26. Masson, Paris, 472 p. (in French) ("The Quaternary Loams of the Seine Basin. Stratigraphy and Paleolithic Archeology”)

Bordes, F. 1961, Typologie du paléolithique ancien et moyen. Publications de l'Institut de préhistoire de l'Université de Bordeaux. Vol. 1. Delmas, Bordeaux, 85 p. (in French) ("The Typology of the Lower and Middle Palaeolithic")

Bordes, F. 1981, Vingt—cinq ans après: le complexe moustérien revisité. Bulletin de la Société Préhistorique Française, 78(3): 77-87. (in French) ("Twenty-five years later: the Mousterian Complex Revisited”). doi:10.3406/bspf.1981.5336

Bordes, F. 1984, Leçons sur le Paléolithique. Le Paléolithique en Europe. Vol. 2. Cahiers du Quaternaire Vol. 7. Éditions du Centre National de Recherche Scientifique, Paris, 459 p. (in French) ("Lessons on the Paleolithic. The Palaeolithic in Europe")

Bordes, F. \& Bourgon, M. 1951, Le complexe Moustérien: moustériens, levalloisien et tayacien. L'Anthropologie, 55(1-2): 1-23. (in French) (“The Mousterian Complex: Mousterian, Levalloisian and Tayacian”)

Bosinski, G. 1963, Eine mittelpaläolithische Formengruppe und das Problem ihrer geochronologischen Einordnung. Eiszeitalter und Gegenwart, 14: 124-140. (in German) ("A Middle Paleolithic Form Group and the Problem of its Geochronological Placement”)

Bosinski, G. 1967, Die Mittelpaläolithischen Funde im westlichen Mitteleuropa. Fundamenta. Monographien zur Urgeschichte Vol. A4. Böhlau, Köln, 206 p. (in German) ("The Middle Paleolithic Finds of western Central Europe”)

Bosinski, G. 1970a, Bemerkungen zu der Grabung D. Peyronys in La Micoque. In: Frühe Menschheit und Umwelt. Archäologische Beiträge Vol. 1 (Gripp, K., Schütrumpf, R. \& Schwabedissen, H., Eds.) Fundamenta. Monographien zur Urgeschichte Vol. A2, Böhlau, Köln: p. 52-56. (in German) ("Notes of the Excavation of D. Peyrony in La Micoque")

Bosinski, G. 1970b, Erwiderung zu der Besprechung meiner Arbeit 'Die mittelpaläolithischen Funde im westlichen Mitteleuropa' durch G. Freund. Quartär, 21: 99-101. (in German) ("Replay on the Review of my Work The Middle Paleolithic Finds of western Central Europe")

Bosinski, G. 1982, The Transition from Lower/Middle Palaeolithic in Northwestern Germany. In: The Transition from Lower to Middle Palaeolithic and the Origin of Modern Man (Ronen, A., Ed.) British Archaeological Reports International Series Vol. 151, Archaeopress, Oxford: p. 165-175. 
Bosinski, G. 2001, El Paleolítico Medio en Europa Central. Zephyrus, 53: 79-142. (in Spanish) (“The Middle Paleolithic in Central Europe”)

Bourguignon, L. 1996, La Conception de Débitage Quina. Quaternaria Nova, 6: 149-166. (in French) ("The Conception of Quina Reduction”)

Bourguignon, L. 1997, Le Moustérien de Type Quina : Nouvelle Définition d'une Entité Technique. Doctoral thesis at Paris X Nanterre-La Defense, Paris, 672 p. (in French) ("The Mousterian of the Quina type: new Definition of a Technical Entity")

Breuil, H. 1932a, Le Paléolithique ancien en Europe Occidentale et sa Chronologie. Bulletin de la Société préhistorique française, 29(12): 570-578. (in French) ("The Lower Palaeolithic in Western Europe and its Chronology”). doi:10.3406/bspf.1932.5670

Breuil, H. 1932b, Les industries à éclat du Paléolithique ancien: I. Le Clactonien. Préhistoire, 1(2): 125-190. (in French) ("The Blank Industries of the Early Paleolithic: I. The Clactonian”)

Cailhol, D. 2014, Étude du karst de la région de Mellecey (Saône et Loire). Project Collective du Recherche: Le Paléolithique supérieur ancien en Bourgogne méridionale. Genèse, chronologie et structuration interne, évolution culturelle et technologique. Rapport annuelle 2014 (Floss, H., Hoyer, C.T., Frick, J.A. \& Herkert, K., Eds.). Unpublished report for the S.R.A. Bourgogne, Dijon, p. 156-171. (in French) ("Study of the Karst of the Region of Mellecey (Saône and Loire)”)

Cailhol, D. 2016, Étude du karst de la région de Mellecey (Saône et Loire). Fouilles programmées pluriannuelles aux sites paléolithiques des Grottes de la Verpillière I \& II à Germolles, commune de Mellecey (Saône-et-Loire). Rapport annuel 2015, Rapport plurianuel 2013-2015 (Floss, H., Hoyer, C.T., Frick, J.A. \& Herkert, K., Eds.). Unpublished report for the S.R.A. Bourgogne, Dijon, p. 388-412 (in French) ("Study of the Karst of the Region of Mellecey (Saône and Loire)")

Chimielewski, W. 1969, Ensembles micoquo-prondnikiens en Europe centrale. Geographica Polonica, 17: 371-386. (in French) (Micoquo-Prondnikian Assemblages in Central Europe)

Conard, N.J. \& Bolus, M. 2003, Radiocarbon dating the appearance of modern humans and timing of cultural innovations in Europe: new results and new challenges. Journal of Human Evolution, 44(3): 331-371. doi:10.1016/s0047-2484(02)00202-6

Cornford, J.M. 1986, Specialized Resharpening Techniques and Evidence of Handedness. In: La Cotte de St. Brelade 1961-1978. Excavations by C.B.M. McBurney (Callow, P. \& Cornford, J.M., Eds.), Geobooks, Norwich: p. 337-351.

Dauvois, M. 1976, Precis de Dessin Dynamique et Structural des Industries Lithiques Préhistoriques. CNRS. Pierre Fanlac, Paris, 263 p. (in French) ("Compendium of Dynamic and Structural Drawings of Prehistorical Lithic Industries”)

Deloze, V., Depaepe, P., Gouédo, J.-M., Krier, V. \& Locht, J.-L. 1994, Le Paleolithique dans le Nord du Senonais (Yonne): Contexte Geomorphologique, Industries Lithiques et Chronostratigraphie. Documents d'archeologie francaise Vol. 47. Maison des Sciences de l'Homme, Paris, 267 p. (in French) ("The Paleolithic in the North of the Senonais (Yonne): Geomorphological Context, Lithic Industries and Chronostratigraphy”)

Depaepe, P. 2014, European Middle Paleolithic: Geography and Culture. In: Encyclopedia of Global Archaeology (Smith, C., Ed.), Springer, New York: p. 2645-2670. doi:10.1007/978-1-4419-0465-2_1850 
Desbrosse, R., Kozlowski, J.K. \& Zuate y Zuber, J. 1976, Prondniks de la France et d'Europe centrale. L'Anthropologie, 80: 431-488. (in French) ("The Prondniks from France and Central Europe")

Desbrosse, R. \& Texier, P.-J. 1973, Les silex de Germolles dans la collection Jeannin. La Physiophile, 79: 64-69. (in French) (“The Germolles Flints in the Jeannin collection”)

Falguères, C., Bahain, J.J. \& Saleki, H. 1997, U-Series and ESR Dating of Teeth from Acheulian and Mousterian Levels at La Micoque (Dordogne, France). Journal of Archaeological Science, 24(6): 537-545. doi:10.1006/jasc.1996.0137

Farizy, C. 1985, Un Habitat du Paléolithique Moyen à Champlost (Yonne, Nord-Bourgogne, France). Archäologisches Korrespondenzblatt, 15(4): 405-410. (in French) (“A Middle Palaeolithic Habitat in Champlost (Yonne, Nord-Bourgogne, France)”)

Farizy, C. 1988, Présentation du Matériel Lithique Provenant du Gisement Moustérien de Champlost (Yonne) et Hypothèses de Fonctionnement du Site. Revue Archéologique de Picardie, 1(1): 141-148. (in French) ("Presentation of the Lithic Material from the Mousterian Site Champlost (Yonne) and Assumptions on the Site's Function”). doi:10.3406/pica.1988.1585

Farizy, C. 1994, Spatial patterning of Middle Paleolithic sites. Journal of Anthropological Archaeology, 13(2): 153-160. doi:10.1006/jaar.1994.1010

Farizy, C. 1995, Industries Charentiennes à Influences Micoquiennes, l'Exemple de l'Est de la France. Paléo Supplément, 1(1): 173-178. (in French) ("Charentian Industries of Micoquian Influences, the Example of the East of France”). doi:10.3406/pal.1995.1393

Floss, H. 1994, Rohmaterialversorgung im Paläolithikum des Mittelrheingebietes. Monographien des Römisch-Germanischen Zentralmuseums Vol. 21. Habelt, Bonn, 407 p. (in German) ("Raw Material Supply at the Paleolithic of the Middle Rhine area")

Floss, H. 2009, Rapport de fouille programmée. Les Grottes de La Verpillière I et II à Germolles. Unpublished report for the S.R.A. Bourgogne, Dijon, 40 p. (in French) ("Excavation Report. The Grottes de la Verpillière I and II at Germolles")

Frick, J.A. 2010, Les outils du Néandertal. Technologische und typologische Aspekte mittelpaläolithischer Steinartefakte, am Beispiel der Grotte de la Verpillière I in Germolles, Commune de Mellecey, Saône-et-Loire (71), Frankreich. Magister's Thesis at the Abteilung für Ältere Urgeschichte und Quartärökologie, Eberhard Karls Universität Tübingen, Tübingen, 280 p. (in German), ("The tools of the Neanderthal. Technological and Typological Aspects of Middle Paleolithic Lithic Artifacts, Exemplified on Grotte de la Verpillière I, Commune of Mellecey, Saône-et-Loire (71), France")

Frick, J.A. 2013, Kostenki-Enden (Dorsalabbau an Grundformen). In: Steinartefakte vom Altpaläolithikum bis in die Neuzeit (Floss, H., Ed.) Tübingen Publications in Prehistory, Kerns Verlag, Tübingen: p. 459-466. (in German) ("Kostenki Knifes (Dorsal Reduction on Blanks)")

Frick, J.A. 2016a, Visualizing Occupation Features in Homogenous Sediments. Examples from the Late Middle Palaeolithic of Grotte De La Verpillière II, Burgundy, France. In: CAA 2015. Keep the Revolution Going. Proceedings of the 43rd Annual Conference on Computer Applications and Quantitative Methods in Archaeology Vol. 1 \& 2 (Campana, S., Scopigno, R., Carpentiero, G. \& Cirillo, M., Eds.), Archaeopress, Oxford: p. 699-713. 
Frick, J.A. 2016b, On technological and spatial patterns of lithic objects. Evidences from the Middle Paleolithic at Grotte de la Verpillière II, Germolles, France. Doctoral thesis at the Abteilung für Ältere Urgeschichte und Quartärökologie, Eberhard Karls Universität Tübingen, Tübingen, 809 p. doi:10.15496/publikation-14816

Frick, J.A. \& Floss, H. 2015, Grotte de la Verpillière II, Germolles, France: Preliminary insights from a new Middle Paleolithic site in southern Burgundy. In: Forgotten Times, Spaces and Lifestyles. New perspectives in paleoanthropological, paleoetnological and archeological studies (Sázelová, S., Novak, M. \& Mizerova, A., Eds.), Institute of Archaeology, CAS, Brno \& Masaryk University, Brno: p. 53-72.

Frick, J.A. \& Floss, H. in press, Analysis of bifacial elements from Grottes de la Verpillière I \& II (Germolles, France). Quaternary International. p. 1-23. doi:10.1016/j.quaint.2015.10.090

Frick, J.A., Herkert, K., Hoyer, C.T. \& Floss, H. 2016, Establishing a cluster of congruent assemblages. The Keilmessergruppen assemblages in the Côte chalonnaise. Unpublished manuscript, p. 30

Frick, J.A. \& Hoyer, C.T. 2009, Grabungs- und Dokumentationshandbuch für Germolles 2009. Unpublished manuscript, Abteilung für Ältere Urgeschichte und Quartärökologie, Universität Tübingen, Tübingen, 120 p. (in German) ("Excavation and Documentation Handbook for the Excavation Germolles 2009”)

Frick, J.A. \& Hoyer, C.T. 2011, Grabungs- und Dokumentationshandbuch für die Grabung Germolles 2011. Unpublished manuscript, Abteilung für Ältere Urgeschichte und Quartärökologie, Universität Tübingen, Tübingen, 120 p. (in German) (“Excavation and Documentation Handbook for the Excavation Germolles 2011”)

Frick, J.A. \& Hoyer, C.T. 2012, Handbuch zur Grabung Germolles 2012. Handbook of the excavation. Unpublished manuscript, Abteilung für Ältere Urgeschichte und Quartärökologie, Universität Tübingen, Tübingen, 120 p. (in German and English) ("Handbook of the Excavation 2012 ")

Frick, J.A., Hoyer, C.T., Heckel, C.E., Herkert, K. \& Floss, H. 2013, Handbuch zu Ausgrabung 2013. Handbook of the Excavation 2013. Unpublished manuscript, Abteilung für Ältere Urgeschichte und Quartärökologie, Universität Tübingen, Tübingen, p. 20. (in German and English) ("Handbook of the Excavation 2013 “)

Frick, J.A., Hoyer, C.T., Herkert, K. \& Floss, H. 2012, Comparative heating experiments on flint from the Côte Chalonnaise, Burgundy, France. Anthropologie (Brno), 50(3): 295321. URL: http://puvodni.mzm.cz/Anthropologie/article.php?ID=1487

Frick, J.A., Hoyer, C.T., Herkert, K. \& Floss, H. 2014, Handbuch zu Ausgrabung 2014. Handbook of the Excavation 2014. Unpublished manuscript, Abteilung für Ältere Urgeschichte und Quartärökologie, Universität Tübingen, Tübingen, p. 20. (in German and English) ("Handbook of the Excavation 2014")

Geneste, J.-M. 1985, Analyse Lithique d'Industries Moustériennes du Périgord: une Approche Technologique du Comportement des Groupes Humains au Paléolithique Moyen. Doctoral thesis at Bordeaux I, Bordeaux, 572 p. (in French) ("Lithic Analysis of Mousterian Industries of Périgord: a Technological Approach to Behavior of Human Groups in the Middle Palaeolithic ") 
Gouédo, J.-M. 1999, Le technocomplexe micoquien en Europe de l'ouest et centrale: exemples de trois gisements du sud-est du basin parisien, Vinneuf et Champlost (Yonne), Verrières-le-Buisson (Essonne). Doctoral thesis at Université des Sciences et Technologies de Lille 1, Lille, 266 p. (in French) ("The Micoquian Technocomplex in Western and Central Europe: Examples from Three Sites from the South-east of the Paris Basin, “Vinneuf and Champlost (Yonne), Verrières-le-Buisson (Essonne)”)

Hahn, J. 1988, Die Geißenklösterle-Höhle im Achtal bei Blaubeuren I. Fundhorizontbildung und Besiedlung im Mittelpaläolithikum und im Aurignacien. Forschungen und Berichte zur Vor- und Frühgeschichte in Baden-Württemberg Vol. 26. Theiss, Stuttgart, 262 p. (in German) ("The Geißenklösterle Cave in the Ach Valley near Blaubeuren I. FindHorizon Formation and Occupation at the Middle Paleolithic and Aurignacian”)

Hauser, O. 1916, Über eine neue Chronologie des mittleren Paläolithikums im Vézèretal: Speziell mit bezug auf meine Ausgrabungen auf la Micoque. Doctoral thesis at the Hohe Philosophische Fakultät, Friedrich-Alexanders-Universität zu Erlangen, Leipzig, 56 p. (in German) ("On a New Chronology of the Middle Paleolithic in the Vézère Valley, particularly with respect on my Excavations at La Micoque”)

Heckel, C., Higham, T.F.G., Hoyer, C.T. \& Floss, H. 2016, Radiocarbon dating of Verpillière I and II. Project Collectif de Recherche: Le Paléolithique supérieur ancien en Bourgogne méridionale. Genèse, chronologie et structuration interne, évolution culturelle et technique. Raport anuell 2015. Abteilung für Ältere Urgeschichte und Quartärökologie, Service Régional d'Archéologie Bourgogne, Tübingen, Dijon, p. 30-37

Herkert, K. in prep, Lithische Ressourcennutzung im späten Mittelpaläolithikum und frühen Jungpaläolithikum der Côte Chalonnaise, Burgund, Frankreich. Doctoral thesis at the Abteilung für Ältere Urgeschichte und Quartärökologie, Eberhard Karls University of Tübingen, Tübingen, p. 300. (in German) ("Lithic Ressource Use in the Late Middle Paleolithic and Early Upper Paleolithic at the Côte Chalonnaise, Burgundy, France”)

Herkert, K., Siegeris, M., Chang, J.-Y., Conard, N.J. \& Floss, H. 2015, Zur Ressourcennutzung später Neandertaler und früher moderner Menschen. Fallbeispiele aus dem südlichen Burgund und der Schwäbischen Alb. Mitteilungen der Gesellschaft für Urgeschichte, 24: 141-172. (in German) ("Ressource use of Late Neanderthals and Early Modern Humans. Case Studies for Southern Burgundy and Swabian Jura”)

Jarvis, A., Reuter, H.I., Nelson, A.J. \& Guevara, E. 2008, Hole-filled seamless SRTM data V4, International Centre for Tropical Agriculture (CIAT), Retrieved June, 2015. URL: http://srtm.csi.cgiar.org/

Jöris, O. 2001, Der spätmittelpaläolithische Fundplatz Buhlen (Grabungen 1966-69): Stratigraphie, Steinartefakte und Fauna des oberen Fundplatzes. Universitätsforschungen zur prähistorischen Archäologie Vol. 73. Habelt, Bonn, 172 p. (in German) (“The Late Middle Paleolithic Site of Buhlen (1966-69 Excavations”)

Jöris, O. 2003, Zur chronostratigraphischen Stellung der spätmittelpaläolithischen Keilmessergruppen: Der Versuch einer kulturgeographischen Abgrenzung einer mittelpaläolithischen Formengruppe in ihrem europäischen Kontext. Bericht der Römisch-Germanischen Kommission, 84: 49-153. (in German) (“On the Chronostratigraphical Position of the Late Middle Paleolithic Keilmessergruppen: The Attempt of a Cultural Geographic Delimination of a Middle Paleolithic Form Group in its European Context”) 
Krukowski, S. 1939-1948, Paleolit. In: Prehistoria ziem polskich (Krukowski, S. \& Kostrezewski, R.J., eds.) Encyklopedia Polska Vol. 4, Drukarnia Uniwersytetu Jagiellonskiego, Kracow: p. 1-117. (in Polish) (“The Palaeolithic”)

Lamotte, A., Aubry, D., Debenham, N., Magniez, P., Le Mene, F. \& Galtier, F. 2012, The Palaeolithic Site of Pont-De-Planches (Haute-Saone, France): Palaeoenvironnement Datas and Datations of Middle Palaeolithic and Upper Palaeolithic Occupations. Quaternaire, 23(4): 291-308. doi:10.4000/quaternaire.6373

Lamotte, A., Chanson, J.-M., Willemann, G. \& Galtier, F. in press, Handaxes and Leafpoints of Eastern France: Spatial Patterns and Role of the Raw Materials. Quaternary International, p. 1-12. doi:10.1016/j.quaint.2015.10.110

Lamotte, A., Huguenin, G., Campy, M., Deherripont, J.-L., Detrey, J., Morin, D. \& Corbeaux, H. 2014, Frettes (Haute-Saône, France): Un Gisement de Plein-air du Paléolithique Moyen, Premiers Résultats. L'Anthropologie, 118(4): 449-475. (in French) (“Frettes (Haute-Saône, France): A Middle Palaeolithic Open-air Site, First Results”). doi:10.1016/j.anthro.2014.10.005

Lamotte, A., Huguenin, G. \& Simonnet, D. 2005, A Propos de la Découverte de Nombreux Indices Micoquiens à Delain (Haute-Saône, France). Notae Prehistoricae, 25: 9-15. (in French) ("About the Discovery of Many Micoquian Indices in Delain (Haute-Saône, France)”)

Mania, D. 1990, Auf den Spuren des Urmenschen: Die Funde aus der Steinrinne von Bilzingsleben. Deutscher Verlag der Wissenschaften, Berlin, 280 p. (in German) (“On the Traces of Prehistoric Man: The Finds from the Stone Canal from Bilzingsleben”)

Méray, C. 1869, L'âge de la pierre à Germolles. Materiaux d'Histoire et d'Archéologie, 5: 8386. (in French) ("The Stone Age from Germolles")

Méray, C. 1876, Compte-Rendu des Fouilles de la Caverne de Germolles, Commune de Mellecey. Mémoires de la Société d'Histoire et d'Archéologie de Chalon-sur-Saône Chalon-sur-Saône, 6(2): 251-266. (in French) ("Report on the Excavations at the Caverne de Germolles, Commune of Mellecey”)

Pastoors, A., Tafelmaier, Y. \& Weniger, G.-C. 2015, Quantifications of late Pleistocene core configurations: Application of the Working Stage Analysis as estimation method for technological behavioral efficieny. Quartär, 62: 63-84. doi:10.7485/QU62_3

Peyrony, D. 1938, La Micoque. Les Fouilles récentes.-Leur signification. Bulletin de la Société Préhistorique Française, 35(6): 257-283. (in French) ("La Micoque. Recent Excavations. - Their Meaning”). doi:10.3406/bspf.1938.12316

Pouliquen, C. 1982a, La collection Lènez: silex taillés de la Roche à Saint-Martin-sousMontaigu. Mémoires de la Société d'Histoire et d'Archéologie de Chalon-sur-Saône Chalon-sur-Saône, 52: 141-152. (in French) ("The Lènez collection: the Chipped Flint from Roche à Saint-Martin-sous-Montaigu”)

Pouliquen, C. 1982b, Le Moustérien de la Roche à Saint-Martin-sous-Montaigu (Saône-etLoire). Collection Lenèz au musée Denon, Chalon-sur-Saône. Diplom thesis at the Institute du Quaternaire, Université de Bordeaux I, Bordeaux, 66 p. (in French) ("The Mousterian of La Roche à Saint-Martin-sous-Montaigu (Saône-et-Loire). Lenèz Collection at the Musée Denon, Chalon-sur-Saône”) 
Pouliquen, C. 1983, Le Moustérien de La Roche à Saint-Martin-sous-Montaigu (Saône-etLoire) d'après la collection Lènez au Musée Denon à Chalon-sur-Saône. Revue Archéologique de l'Est et du Centre-Est Dijon, 133(3-4): 183-207. (in French) ("The Mousterian from La Roche à Saint-Martin-sous-Montaigu (Saône-et-Loire) from the Lènez Collection at the Musée Denon in Chalon-sur-Saône”)

Richard, M., Falguères, C., Ghaleb, B. \& Richter, D. 2016, Résultats préliminaires des datations par ESR/U-Th sur émail dentaire, Grotte de la Verpillière I \& II. Project Collectif de Recherche: Le Paléolithique supérieur ancien en Bourgogne méridionale. Genèse, chronologie et structuration interne, évolution culturelle et technique. Raport anuell 2015 (Floss, H., Hoyer, C.T., Frick, J.A. \& Herkert, K., Eds.). Unpublished report for the S.R.A. Bourgogne, Dijon, p. 11-23. (in French) ("Preliminary Results of Dating with ESR/U-Th on Dental Enamel, Grotte de la Verpillière I \& II”)

Richter, J. 1997, Sesselfelsgrotte III. Der G-Schichten-Komplex der Sesselfelsgrotte. Zum Verständnis des Micoquien. Quartär-Bibliothek Vol. 7. Saarbrückener Druckerei und Verlag, Saarbrücken, 472 p. (in German) ("Sesselfelsgrotte III. The G-level Complex of the Sesselfelsgrotte. On the Comprehension of the Micoquian”)

Richter, J. 2013, Bewusste Geometrische Gestaltung bei Homo Heidelbergensis? Arbeitsschrittanalyse an einem Faustkeil aus Bad Salzuflen (Ostwestfalen-Lippe). Archäologisches Korrespondenzblatt, 43(1): 1-17. (in German) (“Consciously Geometrical Design from Homo heidelbergensis? Working Stage Analysis of a Biface from Bad Salzuflen (Ostwestfalen-Lippe)”)

Rosendahl, G. 2004, Die oberen Schichten von La Micoque (Dordogne, Frankreich). Doctoral thesis at Universität zu Köln, Köln, 166 p. (in German) (“The Upper Levels of La Micoque (Dordogne, France”)

Rosendahl, G. 2006, Les Couches Supérieures de la Micoque (Dordogne). Paléo, 18: 161192. (in French) (“Upper levels of La Micoque (Dordogne)”).

URL: https://paleo.revues.org/209

Rosendahl, G. 2011, Technological Analysis of the Bifacial Tools from La Micoque and Its Implications. In: Neanderthal Lifeways, Subsistence and Technology. One hundred fifty years of Neanderthal study (Conard, N. J., Richter, J., eds), Vertebrate paleobiology and paleoanthropological series, Springer, New York: p. 133-138.

Siegeris, M. in prep, Lithische Rohmaterialien im südlichen Burgund und auf der Schwäbischen Alb - Vom späten Mittel- bis zum frühen Jungpaläolithikum. Doctoral thesis at the Abteilung für Ältere Urgeschichte und Quartärökologie, Eberhard Karls University of Tübingen, Tübingen, p. 300 (in German) ("Lithic Raw Material in Southern Burgundy and on the Swabian Jura - From the Late Middle- to the Early Upper Paleolithic”)

Slimak, L. 2004, Les dernières expressions du Moustérien entre Loire et Rhône. Doctoral thesis at Université de Provence, Aix-en-Provence, 865 p. (in Fench) ("The last Expressions of the Mousterian between Loire and Rhône”)

Terradas, X. 2003, Discoid flaking method: conception and technological variability. In: Discoid Lithic Technology: Advances and Implications (Peresani, M., Ed.) British Archaeological Reports International Series Vol. 1120, Archaeopress, Oxford: p. 19-32.

Tixier, J. \& Turq, A. 1999, Kombewa et alii. Paléo, 11(1): 135-143. (in French) ("Kombewa and others) doi:10.3406/pal.1999.1174 
Turq, A. 1989, Approche technologique et économique du faciès Moustérien de type Quina: Étude préliminaire. Bulletin de la Société Préhistorique Française, 86(8): 244-256. (in French) ("Technological and economic approach of the Quina type Mousterian facies") doi:10.3406/bspf.1989.9390

Van Peer, P. 1992, The Levallois reduction strategy. Monographs in World Archaeology Vol. 13. Prehistory Press, Madison, 137 p.

Veil, S., Breest, K., Höfle, H.C., Meyer, H.H., Plisson, H., Urban-Küttel, B., Wagner, G.A. \& Zöller, L. 1994, Ein mittelpaläolithischer Fundplatz aus der Weichsel-Kaltzeit bei Lichtenberg, Lkr. Lüchow-Dannenberg. Germania, 72(1): 1-66. (in German) (“A Middle Paleolithic Site from the Weichsel Glacial near Lichtenberg, Rural district of Lüchow-Dannenberg”)

Weißmüller, W. 1995, Sesselfelsgrotte II. Die Silexartefakte der Unteren Schichten der Sesselfelsgrotte. Ein Beitrag zum Problem des Moustérien. Quartär-Bibliothek Vol. 6. Saarbrückener Druckerei und Verlag, Saarbrücken, 555 p. (in German) ("Sesselfelsgrotte II. The Silex Artifacts of the Lower Levels of the Sesselfelsgrotte. A Contribution to the Problem of the Mousterian”)

Wilk, A. 2014a, Détermination ostéologique et évaluation archéozoologique des vestiges fauniques des Grottes de la Verpillière à Germolles. In: Les Grottes de la Verpillière à Germolles, commune de Mellecey (Saône-et-Loire). Fouille programmée pluriannuelle 2013-2015. Rapport intermédiaire 2013. (Floss, H., Hoyer, C.T., Frick, J.A. \& Herkert, K., Eds.). Unpublished report for the S.R.A. Bourgogne, Dijon, p. 107-113. (in French) ("Osteological Determination and Archeozoological Evaluation of Faunal Finds of the Grottes de la Verpillière in Germolles”)

Wilk, A. 2014b, Die Tierknochenfunde aus Germolles, Grottes de la Verpillière. Archäozoologische Bestimmung. In: Projet Collectif de Recherche: Le Paléolithique supérieur ancien en Bourgogne méridionale. Genèse, chronologie et structuration interne, évolution culturelle et technologique. Rapport annuel 2014 (Floss, H., Hoyer, C.T., Frick, J.A. \& Herkert, K., Eds.). Unpublished report for the S.R.A. Bourgogne, Dijon, p. 214-224. (in German) ("The Animal-bone Finds from Germolles, Grottes de la Verpillière: Archeozoological Determination”)

Wißing, C. 2012, Geoarchäologische Untersuchungen in Germolles. Strukturgeologische, paläontologische und mikromorphologische Untersuchungen des Fundstellenkomplexes der Verpillière Höhlen und deren Umfeld in Germolles, Commune de Mellecey, Saôneet-Loire (71), Frankreich. Magister's thesis at the Abteilung für Ältere Urgeschichte und Quartärökologie, Universität Tübingen, Tübingen, p. 118. (in German)

("Geoarcheological Studies in Germolles. Structural Geological, Paleontological and Micromorphological Studies of the Site Complex of the Verpillière Caves and their Surrounding in Germolles, Commune of Mellecey, Saône-et-Loire (71), France”)

Zöller, L. \& Schmidt, C. 2016, Germolles - Grotte de la Verpillière II - GH 3 \& 4, Report on luminescence dating of cave sediments. Project Collectif de Recherche: Le Paléolithique supérieur ancien en Bourgogne méridionale. Genèse, chronologie et structuration interne, évolution culturelle et technique. Raport anuell 2015. (Floss, H., Hoyer, C.T., Frick, J.A. \& Herkert, K., Eds.). Unpublished report for the S.R.A. Bourgogne, Dijon, p. 45-49.

Zotz, L.F. 1951, Altsteinzeitkunde Mitteleuropas. Enke, Stuttgart, p. 280. (in German) ("Paleolithic Study of Central Europe") 